Progress in Human Development - Are we on the right path?

Hippu Salk Kristle Nathan and Srijit Mishra

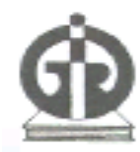

Indira Gandhi Institute of Development Research, Mumbai

July 2010

http://www.igidr.ac.in/pdf/publication/WP-2010-010.pdf 


\title{
Progress in Human Development - Are we on the right path?
}

\author{
Hippu Salk Kristle Nathan and Srijit Mishra \\ Indira Gandhi Institute of Development Research (IGIDR) \\ General Arun Kumar Vaidya Marg \\ Goregaon (E), Mumbai- 400065, INDIA \\ Email (corresponding author): $\quad$ srijit@igidr.ac.in
}

\begin{abstract}
The conventional measure of Human Development Index (HDI) is a linear average across dimensions, HDI1. Under this, poor attainments in any dimension gets perfectly compensated for better attainments in any other dimension HDI2, which is based on Euclidean distance measuring shortfall from the ideal, addresses the above anomaly. In our analysis of progress, we use HDI2 to develop the notion of an ideal path and penalty to capture deviation from this; and a measure of fluctuation. The measures are applied to 127 countries for the period 1990-2004. The results show that Sub-Saharan countries have suffered on account of sharp decline in health suggesting prevalence of human immunodeficiency virus/acquired immune deficiency syndrome (HIV/AIDS) epidemic. In case of Commonwealth of Independent States (CIS), the income dimension got jolted in the nineties indicating their economic collapse after Soviet disintegration. We also find some of the emerging economies progressing well along the ideal path. On the eve of the 20th anniversary of Human Development Report, this paper is timely and would engage academia and public policy to have a critical look favouring a balanced development across the three dimensions of HDI - health, education and standard of living.
\end{abstract}

\section{Keywords:}

Human Development Index (HDI), Ideal path, Measure of fluctuation, Measure of normalized-change, Sub-Saharan, Commonwealth of Independent States (CIS)

\section{JEL Code:}

$\mathrm{C} 43, \mathrm{I} 00, \mathrm{O} 15$

\section{Acknowledgements:}

This paper is forthcoming in the International Journal of Economic Policy in Emerging Economies. The authors are thankful to an anonymous reviewer for insightful comments and suggestions. 


\title{
Progress in Human Development - Are we on the right path?
}

\author{
Hippu Salk Kristle Nathan and Srijit Mishra
}

\section{$1 \quad$ Introduction}

The history of Human Development Index (HDI) is relatively short. Since the inception of HDI by the United Nation Development Programme (UNDP) in 1990, it has gone through various refinements and contributed to policy discourse. ${ }^{1}$ It also has its share of criticisms. ${ }^{2}$ Nevertheless, wide acceptance of HDI can be attributed to the following reasons. HDI has been successful in taking the debate from a one-dimensional income-based measure like Gross National Product (GNP) to a three-dimensional measure based on education, health and income. There has been a paradigm shift in terms of consideration of human beings as ends, rather than means of production only. Further, annual computation of HDI and its components through Human Development Reports (HDRs) allows cross-sectional comparison of relative position of countries and provided the scope for time series study on the movement of countries in HDI space. In this paper, we intend to analyse the trends in HDI for selected countries for the time period 1990 to 2004.

In human development, each dimension is intrinsic (Sen, 1999). And hence, if attainment in any dimension is relatively lower, future emphasis ought to be more towards this dimension. A study on movement of countries in HDI space over time reveals how the countries have given relative importance to different dimensions. To illustrate, let us consider the Sub-Saharan Africa region where poor health infrastructure coupled with the human immunodeficiency virus/acquired immune deficiency syndrome (HIV/AIDS) epidemic has

\footnotetext{
${ }^{1}$ For evolution of HDI see Desai (1991), Streeten (1994), Haq (1995), Sen (2000), Raworth and Stewart (2003), and Jahan (2003) among others.

${ }^{2}$ One of the major criticisms of HDI is its use of income component, which may be partly correlated to health and education dimensions. However, inclusion of income in 'HDI is strictly as a residual catch-all, to reflect something of other basic capabilities not already incorporated in the measures of longevity and education.' (Anand and Sen, 2000, p.86).
} 
led to a low life expectancy. ${ }^{3}$ Consequently, the countries of the region do not fair well in the health dimension of HDI. For example, in 2005 Swaziland's health index is 0.265 (average life expectancy 40.9 years), whereas the education and income indices are 0.730 and 0.647 respectively (UNDP, 2007). Hence, Swaziland should give higher importance to health dimension, otherwise what relevance is higher level of education and income for people if they are not going to live beyond 40 years!

\section{Two methods of construction of HDI}

The normalized scores in three dimensions of heath $(h)$, education $(e)$ and income $(y)$ are aggregated to construct HDI by two techniques. The conventional method can be termed as 'linear averaging' (LA), which assumes perfect substitutability across the dimensions. ${ }^{4}$ It is expressed as

$$
H D I_{1}=\frac{h+e+y}{3}
$$

The second method of computation of HDI is based on 'displaced ideal' (DI) method, where the index is calculated as the inverse of the Euclidian distance measuring shortfall from the ideal. HDI under DI is expressed as

$$
H D I_{2}=1-\frac{\sqrt{(1-h)^{2}+(1-e)^{2}+(1-y)^{2}}}{\sqrt{3}} .
$$

Based on Minkowski distance function, these two turn out to be first and second order measures of an $\alpha$-class of human development indices, ${ }^{5}$

$$
H D I_{\alpha}=1-\left(\frac{(1-h)^{\alpha}+(1-e)^{\alpha}+(1-y)^{\alpha}}{3}\right)^{\frac{1}{\alpha}} \alpha=[1, \infty)
$$

\footnotetext{
${ }^{3}$ All the countries which have average life expectancy less than 50 years belong to this region (UNDP, 2007).

${ }^{4}$ Perfect substitutability means that any increment in one dimension at any value can be substituted or neutralized by an equal decrement in another dimension at any other value.

${ }^{5}$ The difference between LA and DI methods and $\alpha$-class of HDI measures based on Minkowski distance function are discussed in Nathan, Mishra and Reddy (2008) and Mishra and Nathan (2008) respectively.
} 
Figure 1 shows HDI space in two dimensions by taking health and education for illustration. There is an increment in HDI from any position $j$ to a certain higher value for which iso-HDI lines are plotted for $\mathrm{HDI}_{1}$ and $\mathrm{HDI}_{2}{ }^{6}$ All the points in iso-HDI line are first order equidistant from $j$ as the algebraic sum of movement from $j$ to any of the points in iso$\mathrm{HDI}_{1}$ is constant. Thus, under $\mathrm{HDI}_{1}$, increment remains path-invariant. However, the second order distance from $j$ to different points in iso- $\mathrm{HDI}_{2}$ vary and it minimises at $k$, which is along the line joining $j$ and ideal, $I$. This brings us to the notion of ideal path and path penalty.

Figure $1 \mathrm{HDI}_{1}, \mathrm{HDI}_{2}$ and ideal path

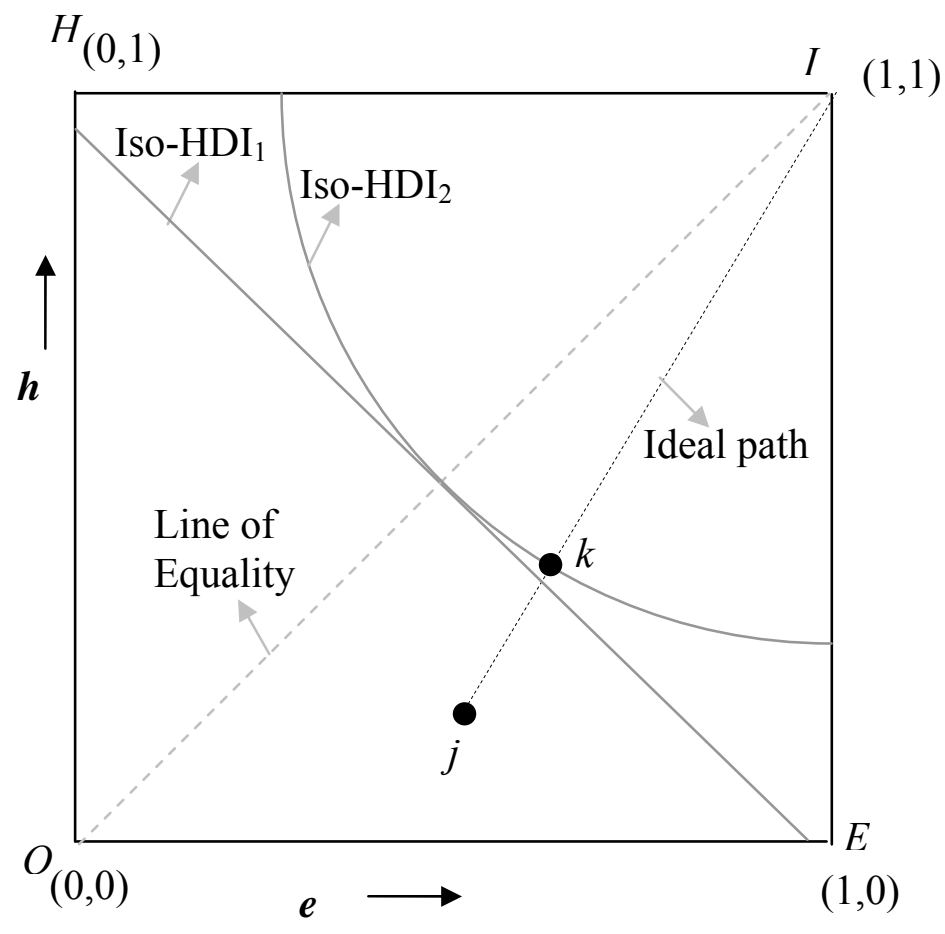

Note: Line of equality gives the locus of all points for which all dimensions share equal values; thence on line of equality $\mathrm{HDI}_{1}=\mathrm{HDI}_{2}$.

\section{$3 \quad$ Ideal path and path penalty}

$\mathrm{HDI}_{2}$ signals the societies to progress along an ideal path which is based on the notion that improvement in a dimension that has lower value is more important than an equivalent

\footnotetext{
${ }^{6}$ In HDI space, the iso-HDI ${ }_{1}$ loci are inclined triangular planes indicating same $\mathrm{HDI}_{1}$, the corresponding locus in two dimension will be $45^{0}$ inclined (or backward hatched) lines. For $\mathrm{HDI}_{2}$, concentric quarter spheres with centre being ideal are iso- $\mathrm{HDI}_{2}$ loci indicating common $\mathrm{HDI}_{2}$, the corresponding locus in two dimensions are concentric quarter circles.
} 
improvement in a dimension that has higher value. Figure 1 shows the ideal path, $j I$, for a given position $j$. Ideal path gives the direction of progress where the emphases along the dimensions are in proportion to their respective shortfall. In other words, given a position and increment, improvement in $\mathrm{HDI}_{2}$ is maximized when the movement is along the ideal path.

Any deviation from the ideal path is captured through path penalty, Figure 2. For any path, say $j l$, path penalty, $Q_{j l}$, is the excess distance covered to reach ideal, ${ }^{7}$

$$
Q_{j l}=j l+l I-j I
$$

\section{Figure 2 Path penalty}

$$
(0,1)
$$

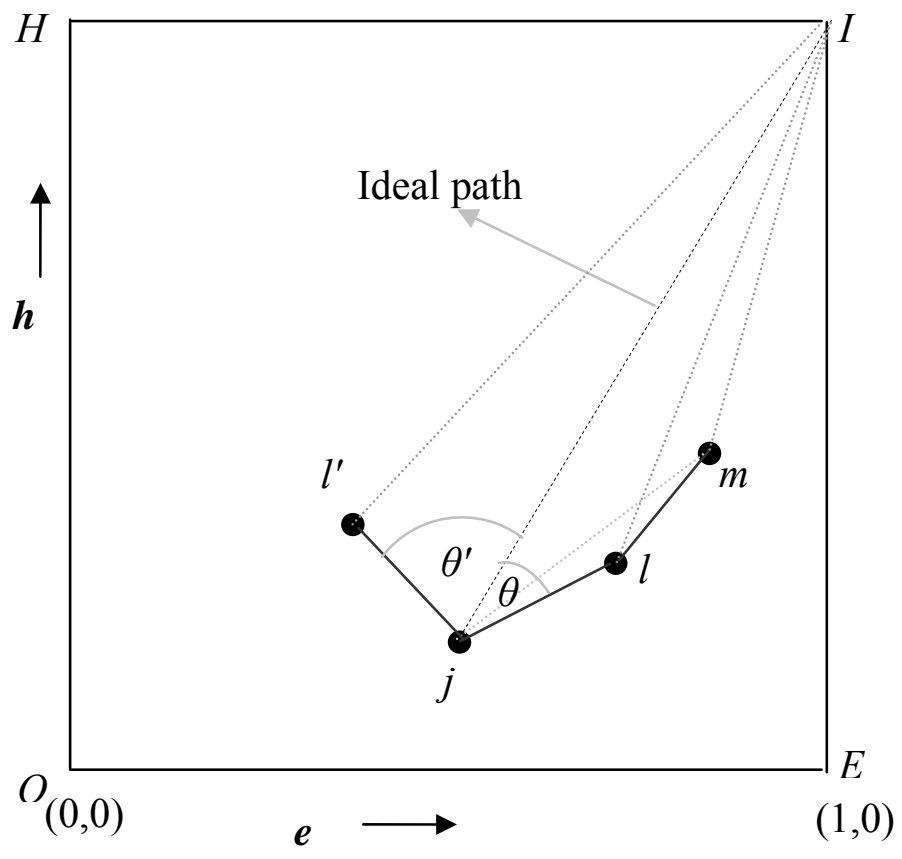

Further, greater is the deviation from the ideal path, the higher is the penalty. Mathematically, from Figure 2, if $\theta^{\prime} \geq \theta$ and $j l^{\prime} \geq j l$ then $Q_{j l}>Q_{j l}$. The normalized penalty can be obtained as ${ }_{N} Q_{j}=Q_{j l} / 2 \sqrt{ } 2 .^{8}$

For a further movement, say $l m$, the path penalty is given by $Q_{l m}=(l m+m I-l I)$. Cumulative path penalty, $Q^{c}$, for $j$ to $m$ through $l, Q^{c}=Q_{j l}+Q_{l m}=(j l+l m+m I-j I)$. Thus

\footnotetext{
${ }^{7}$ Under $\mathrm{HDI}_{1}$, path penalty is zero as the first order distance $j l+l l=j I$.

${ }^{8}$ Normalized path penalty is obtained by dividing by maximum possible path penalty, which is $2 \sqrt{ } 2$, that is, for the path from ideal, $I$ to origin, $O$.
} 
generalizing, for a series of movements $\left(s_{1}, s_{2}, . ., s_{n}\right)$ cumulative path penalty is obtained by summing up of the distances between consecutive positions and adding to it the distance from the last position to the ideal and subtracting from this the distance between the initial position and the ideal,

$$
Q^{c}=\sum_{1}^{n-1} s_{i} s_{i+1}+s_{n} I-s_{1} I
$$

If the path is closed, that is, the country returns back to the original position, then $Q^{c}=\sum s_{i} s_{i+1}$, as the last two terms cancel each other. The cumulative penalty can be normalized as ${ }_{N} Q^{c}=Q^{c} /(2 n \sqrt{2})$, where $n$ is the number of path segments between the first and last positions.

\section{$4 \quad$ A measure of fluctuation}

For a given initial position $\left(s_{1}\right)$ and final position $\left(s_{n}\right)$, the movement is minimized when the intermediate positions $\left(s_{2}, s_{3}, . ., s_{n-1}\right)$ lie on the straight line $s_{1} s_{n}$. Thus, for a given series of positions $\left(s_{1}, s_{2}, . ., s_{n}\right)$, a measure of fluctuation, $F$, can be conceptualized as,

$$
F=1-\frac{s_{1} s_{n}}{\sum_{1}^{n-1} s_{i} s_{i+1}},
$$

where $\sum s_{i} s_{i+1}$ is the actual distance in the movement from $s_{1}$ to $s_{n}$.

\subsection{Properties of $F$}

Normalization: A measure for fluctuation in HDI movement has a minimum and a maximum $F \in[0,1]$. At its minimum, $F=0$ corresponds to single straight line movement. At its maximum, $F=1$ indicates movement along closed path.

Monotonicity: Higher the fluctuation in movement, greater is $F$. In other words, $F$ will increase (decrease) if the ratio of minimum distance to actual distance increases (decreases).

\section{A measure of normalized-change in HDI}

To assess change in human development a measure is conceptualized to capture reduction in shortfall or attainment. This is calculated by taking positive change as a ratio of the initial 
shortfall and negative change as a ratio of the initial achievement. This measure of normalized-change is indicated as,

$$
\begin{gathered}
G_{\alpha}=\frac{H D I_{\alpha l}-H D I_{\alpha j}}{1-H D I_{\alpha j}} \text { if } H D I_{\alpha l}>H D I_{\alpha j} \\
=\frac{H D I_{\alpha l}-H D I_{\alpha j}}{H D I_{\alpha j}} \text { if } H D I_{\alpha l}<H D I_{\alpha j} ;
\end{gathered}
$$

where $H D I_{\alpha j}$ and $H D I_{\alpha l}$ correspond to initial and final value in a movement. This has been computed for both $\mathrm{HDI}_{1}$ and $\mathrm{HDI}_{2}$ and discussed in the empirical section. Figure 3 shows $G_{1}$ and $G_{2}$ for a two dimensional case $(h, e)$.

\section{Figure 3 Measure of normalized-change in HDI}

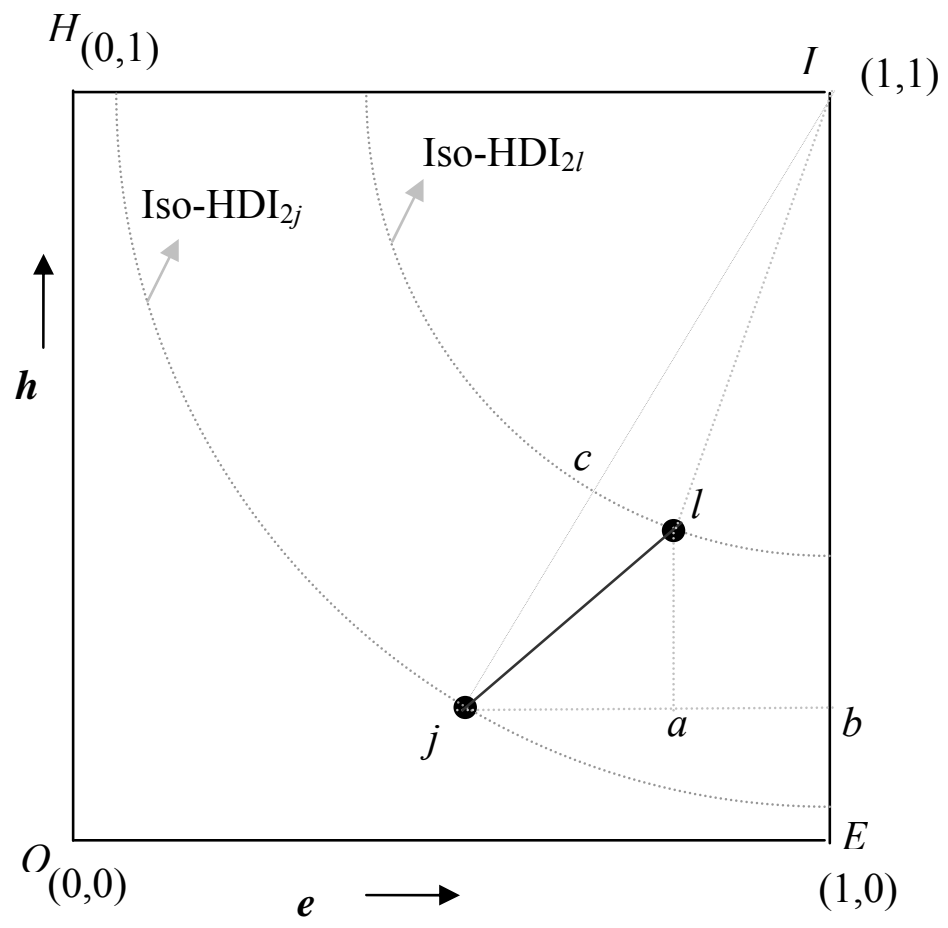

Note: Geometrically, $G_{1}=(j a+l a) /(j b+I b)$ and $G_{2}=I c / I j$.

\subsection{Properties of $G$}

A measure of normalized-change in HDI has the following axiomatic properties.

Normalization: A measure for normalized-change in HDI has a minimum and a maximum $G \in[-1,1]$. At its minimum, $G=-1$ indicates that with the change there is complete failure in all the dimensions $(h=0, e=0, y=0)$. At its maximum, $G=1$ indicates that with the 
change there is full attainment in all the dimensions $(h=1, e=1, y=1)$. For, $G=0$, there is no change. Both $G_{1}$ and $G_{2}$ satisfy normalization. For $j I, G_{\alpha}=1$ and for $j O, G_{\alpha}=-1$.

Monotonicity: A measure for normalized-change in HDI will increase (decrease) if the final HDI value increases (decreases) with the initial value remaining constant. If initial and final $\mathrm{HDI}$ are denoted as $\mathrm{HDI}_{\alpha j}$ and $\mathrm{HDI}_{\alpha l}$ respectively then with two countries $c_{1}$ and $c_{2}$ this would mean that for $\mathrm{c}_{1} \mathrm{HDI}_{\alpha j}=\mathrm{c}_{2} \mathrm{HDI}_{\alpha j} ; \mathrm{c}_{1} G_{\alpha} \gtrless \mathrm{c}_{2} G_{\alpha}$ iff $\mathrm{c}_{1} \mathrm{HDI}_{\alpha l} \gtrless \mathrm{c}_{2} \mathrm{HDI}_{\alpha l}$. Both $G_{1}$ and $G_{2}$ satisfy this. For a given initial position, $j$, and final positions $l$ and $l^{\prime} ; G_{\alpha j l}>G_{\alpha j l}{ }^{\prime}$ as $\operatorname{HDI}_{\alpha l}>\mathrm{HDI}_{\alpha, l}$ '

Signalling at aggregate level: A measure for normalized-change in HDI should signal countries at lower level of HDI to improve more than the countries at higher level. In other words to attain the same change in HDI the country with a higher shortfall has to improve more than the countries at lower shortfall. Putting differently, stagnancy in HDI in a country that has a lower value is more serious. This axiom supports the view that emphasis (both society's internal drive and more so for external assistance) ought to be relatively more for countries at lower level of HDI. Both $G_{1}$ and $G_{2}$ satisfy this axiom as from (7) at a lower (higher) level of HDI, we start with a higher (lower) base for positive change and lower (higher) base for negative change.

Signalling at component level: ${ }^{9}$ A measure for normalized-change in HDI should signal a country to emphasize more on the dimension that has a lower value. This is in line with the notion of human development that each dimension is intrinsic (Sen 1999); and for progress, the country needs to do well in all dimensions. A corollary to this axiom is that an improvement in a dimension that has lower value bears greater importance. $G_{1}$ fails to satisfy this axiom, whereas $G_{2}$ satisfies. This follows from the discussion on path penalty.

\footnotetext{
${ }^{9}$ This axiom is same as the signalling axiom imposed on the class of HDI measure proposed in a companion paper.
} 


\subsection{Positive and negative values of $G$}

The rise and fall in HDI is indicated by positive and negative value of $G$. Figure 5 shows for a given position, $j$, the positive and negative zones of $G_{1}$ and $G_{2}$.

For a given position, $j$, values of both $G_{1}$ and $G_{2}$ coincide on the ideal path, $j I$. Geometrically the same can be inferred from Figure 5, for a movement $j k$ on ideal path; from isosceles triangles $j a k$ and $j b I, G_{1}=(j a+a k) /(j b+b I)=j k / j I=G_{2}$. Similarly for a movement along the line joining the position and origin, $j O$, both $G_{1}$ and $G_{2}$ are negative and equal.

Normalized-change in HDI in conjunction with path penalty appraises the progress in human development for countries. We illustrate this below.

\section{Figure 4 Positive and negative zones of $G_{1}$ and $G_{2}$}

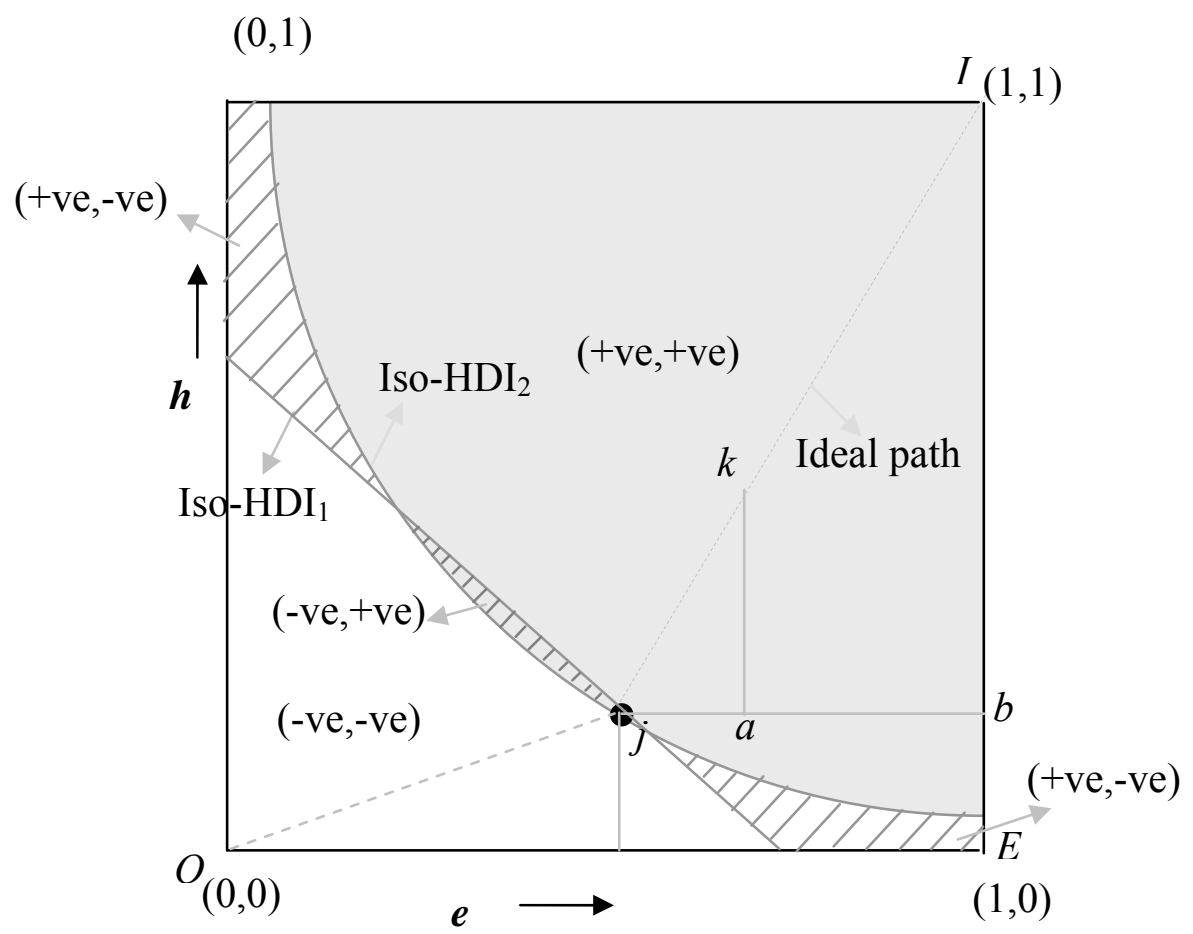

Note: The shaded area corresponds to a zone where both $G_{1}$ and $G_{2}$ are positive. The hatched area corresponds to positive $G_{1}$ and negative $G_{2}$. The shaded cum hatched zone corresponds to negative $G_{1}$ and positive $G_{2}$ and the plain area corresponds to both $G_{1}$ and $G_{2}$ being negative. 


\section{$6 \quad$ Empirical illustration}

By using comparable time series data obtained from Human Development Report Office the normalized-change in HDI is computed for 127 countries between the year 1990 and 2004. The countries are ranked both on the basis of $G_{1}$ and $G_{2}$. The difference in ranks indicates that a positive (negative) value implies a better (worse) performance of the country with $\mathrm{HDI}_{2}$ compared with $\mathrm{HDI}_{1}$. We also compute the normalized cumulative path penalty, ${ }_{\mathrm{N}} Q^{c}$, for the study period by combining the path penalties for $1990-95,1995-2000$, and 2000 04. Appendix 1 gives these values. ${ }^{10}$

\subsection{Fall in HDI}

Out of 127 countries under consideration, 111 countries show improvement in HDI from 1990 to 2004 both under $\mathrm{HDI}_{1}$ and $\mathrm{HDI}_{2}$. We refer to these countries as gainers. The rest 16 countries, which are referred as losers, are listed in Table 1. These countries in general are characterized by high path penalty, ${ }_{\mathrm{N}} Q^{c}$, indicating movement away from ideal path.

The five biggest losers, who have same ranks under $G_{1}$ and $G_{2}$, are all from SubSaharan region. Barring $\mathrm{HDI}_{1}$ for Lesotho and South Africa for the period of 1990-95, these countries have experienced fall in HDI in all the three time periods viz. 1990-95, 1995-2000 and 2000-04. This fall is mostly attributed to poor health condition in the region, which is evident from the steep decline in life expectancy in the countries. The decline in health dimension has overtaken the improvements in other dimensions and made HDI to fall. For example, Botswana's life expectancy index, $h$, is $0.680,0.569,0.309$ and 0.165 for 1990, 1995, 2000 and 2004 respectively. The corresponding education and income indices $(e, y)$ are $(0.679,0.683),(0.718,0.692),(0.744,0.739)$ and $(0.773,0.768)$. The movement of Botswana is shown in Figure 5, in a two-dimensional HDI space $(h, e)$. The widely deviated movement from ideal path has resulted in high penalty for Botswana (highest among 127 countries).

\footnotetext{
${ }^{10} \mathrm{In} \mathrm{HDI}_{2}$ calculations, education index is computed using DI method between adult literacy and gross enrolment. The intermediate years 1995 and 2000 are chosen on the basis of availability of data.
} 
Table 1: The losers

\begin{tabular}{|c|c|c|c|c|c|c|c|c|c|c|c|c|c|c|}
\hline \multirow[t]{2}{*}{ Country } & \multicolumn{4}{|c|}{$\mathrm{HDI}_{1}$} & \multicolumn{4}{|c|}{$\mathrm{HDI}_{2}$} & \multirow{2}{*}{$\begin{array}{c}G_{1} \\
(1990- \\
2004)\end{array}$} & \multirow{2}{*}{$\begin{array}{c}G_{1} \\
\text { Rank, } \\
R_{l}\end{array}$} & \multirow{2}{*}{$\begin{array}{c}G_{2} \\
(1990- \\
2004) \\
\end{array}$} & \multirow{2}{*}{$\begin{array}{c}G_{2} \\
\text { Rank, } \\
R_{2}\end{array}$} & \multirow{2}{*}{$\begin{array}{c}\text { Rank } \\
\text { Diff } \\
\left(R_{1}-R_{2}\right)\end{array}$} & \multirow[t]{2}{*}{${ }_{\mathrm{N}} Q^{c}$} \\
\hline & 1990 & 1995 & 2000 & 2004 & 1990 & 1995 & 2000 & 2004 & & & & & & \\
\hline Zimbabwe & 0.639 & 0.591 & 0.525 & 0.494 & $\overline{0.630}$ & 0.564 & 0.477 & 0.439 & -0.2263 & 127 & -0.3035 & 127 & 0 & 0.0716 \\
\hline Botswana & 0.680 & 0.660 & 0.598 & 0.568 & 0.681 & 0.654 & 0.551 & 0.484 & -0.1645 & 125 & -0.2890 & 125 & 0 & 0.0842 \\
\hline Lesotho & 0.572 & 0.573 & 0.524 & 0.501 & 0.560 & 0.560 & 0.487 & 0.441 & -0.1251 & 124 & -0.2122 & 124 & 0 & 0.0593 \\
\hline South Africa & 0.735 & 0.741 & 0.691 & 0.662 & 0.723 & 0.717 & 0.658 & 0.603 & -0.0991 & 123 & -0.1653 & 123 & 0 & 0.0470 \\
\hline Zambia & 0.464 & 0.425 & 0.409 & 0.437 & 0.452 & 0.404 & 0.382 & 0.399 & -0.0587 & 120 & -0.1166 & 122 & -2 & 0.0300 \\
\hline Moldova & 0.740 & 0.683 & 0.679 & 0.696 & 0.714 & 0.637 & 0.627 & 0.648 & -0.0592 & 121 & -0.0923 & 120 & 1 & 0.0316 \\
\hline Tajikistan & 0.697 & 0.631 & 0.627 & 0.652 & 0.657 & 0.571 & 0.567 & 0.598 & -0.0646 & 122 & -0.0899 & 119 & 3 & 0.0335 \\
\hline Ukraine & 0.800 & 0.748 & 0.755 & 0.774 & 0.781 & 0.720 & 0.720 & 0.744 & -0.0326 & 118 & -0.0476 & 118 & 0 & 0.0279 \\
\hline $\begin{array}{l}\text { Russian } \\
\text { Federation }\end{array}$ & 0.818 & 0.771 & 0.785 & 0.797 & 0.795 & 0.746 & 0.754 & 0.764 & -0.0259 & 116 & -0.0390 & 117 & -1 & 0.0231 \\
\hline Côte d'Ivoire & 0.443 & 0.428 & 0.427 & 0.430 & 0.442 & 0.430 & 0.429 & 0.431 & -0.0309 & 117 & -0.0244 & 116 & 1 & 0.0179 \\
\hline Cameroon & 0.515 & 0.495 & 0.502 & 0.524 & 0.515 & 0.497 & 0.494 & 0.503 & 0.0189 & 113 & -0.0235 & 115 & -2 & 0.0232 \\
\hline
\end{tabular}


There are six more Sub-Saharan countries, other than the bottom five, which find place in the losers list. These countries are also characterized by low life expectancies. From the HDI values it is apparent that these countries are on the recovery path since 2000 . This can be attributed to various recent global and local health initiatives in the region and the progresses in some countries thereof. For example, in Ethiopia, Malawi, Mozambique, Namibia, Niger, Rwanda and Tanzania the under-five mortality rates have declined by more than 20 percent between 2000 and 2004 (UNICEF, 2007). Also, the incidence and prevalence of HIV/AIDS has slowed down in the region (UNAIDS, 2008). The reforms in governance and distributive systems coupled with mechanism to safeguard people against risks have also been instrumental for progress in the region (Fosu and Mwabu, 2010). As per Global Monitoring Report (GMR), 2007, real per capita income growth in the region's low-income countries has been stronger since 2000 than in any period since the 1960 s.

Figure 5 Movement of Botswana in HDI space (h,e), 1990-2004

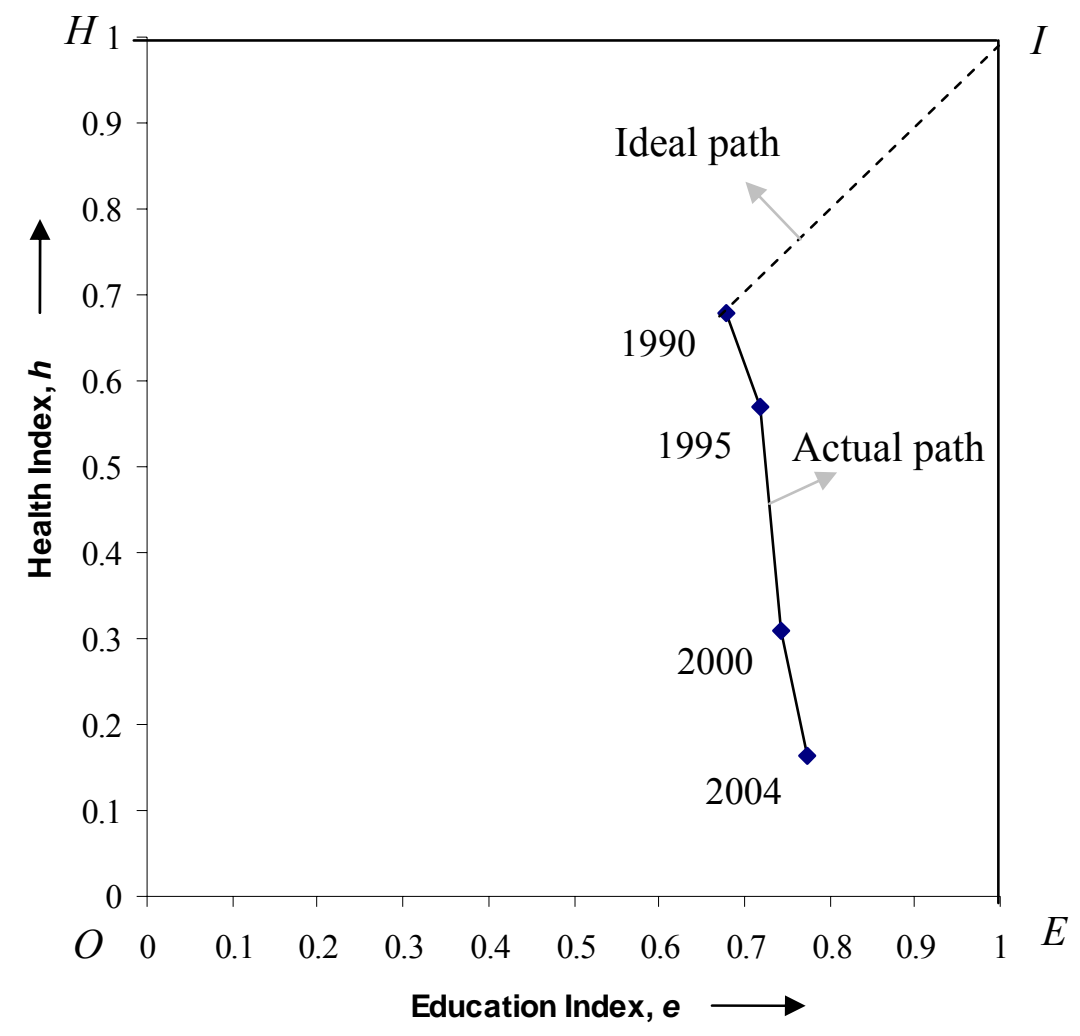


The other countries in Table 1 are from Commonwealth of Independent States (CIS). One observes a decline in all the three dimensions of human development between 1990 and 1995 , that is, the period immediately after the disintegration of the Soviet Union. This is largely on account of an economic collapse and fall in real outputs (Campos and Coricelli, 2002; World Bank, 2002; Linn, 2004). This gets reflected in the sharp decline in income indices for these countries. Since the late nineties all these countries have started a sustained recovery process (Linn, 2004), and this economic revival is attributed to political and macroeconomic stability, structural and institutional reform, upturn in agriculture, foreign direct investment (FDI) inflows among other reasons (Dowling and Wignaraja, 2005; International Monetary Fund (IMF), 2005; Dowling and Wignaraja, 2006).

\section{Figure 6 Movement of Moldova in HDI space $(y, h), 1990-2004$}

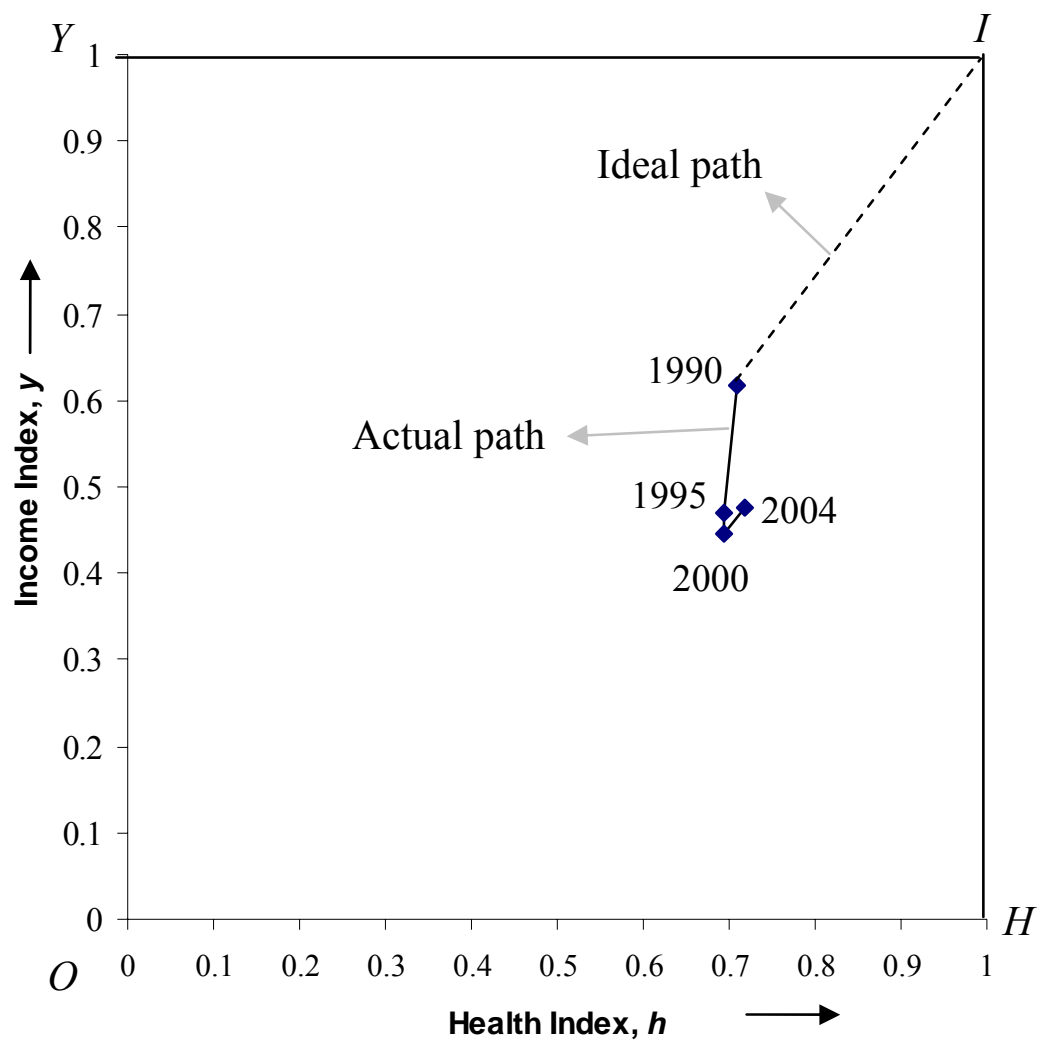

The case of CIS can be illustrated by considering the case of Moldova. Its health, education and income indices $(h, e, y)$ are $(0.709,0.892,0.618),(0.695,0.886,0.469)$, $(0.693,0.897,0.446)$ and $(0.718,0.894,0.476)$ for 1990, 1995, 2000 and 2004 respectively, 
which shows Moldova has steadied in health and education dimension in the study period after the initial hiccup. However, the income dimension has shown sharp decline till the second half of the nineties and is on the recovery since then. The movement of Moldova has been shown in Figure 6, in two-dimensional HDI space $(y, h)$.

Among the 16 losers, $G_{1}$ is positive for three countries, namely, Cameroon, Tanzania and Kazakhstan. This is because, the algebraic sum of progress in three dimensions for these countries for the time period 1990-2004 turns out to be positive. However from the individual dimensions, it is seen that there is improvement in a better performing dimension and decline in a lower performing dimension, and hence, cannot substitute each other under $\mathrm{HDI}_{2}$. For instance, Cameroon's health index fell from 0.465 to 0.344 whereas its education index rose from 0.561 to 0.713 . The difference being larger in the later, $\mathrm{HDI}_{1}$ is positive. But, health being the lower performing dimension the negative movement because of decline in health

index turns out to be more than the positive movement on account of improvement in education dimension under $\mathrm{HDI}_{2}$. This point is further substantiated by considering some cases from gainers.

\subsection{Rise in $H D I$}

Table 2 lists some of the gainers. The countries whose ranks differed under $G_{1}$ and $G_{2}$ are considered in pair wise fashion to highlight the contrast. In general, the countries which got lower rank as per $G_{2}$ than $G_{1}$ are characterized by high path penalty, ${ }_{\mathrm{N}} Q^{c}$. Some of the selected countries movements from 1990 to 2004 have been shown in Figure 7 in the two dimensional HDI space $(y, e)$.

The income index of Equatorial Guinea, a Sub-Saharan country, has more than doubled during 1990-2004. However the health dimension has suffered because of the regional characteristics of infant/child mortality, malnourishment, and HIV/AIDS infections. Compared to Equatorial Guinea, the northeastern African country of Sudan has moved in 
health and income dimension in proportion to their respective shortfall, that is, along the ideal path (Figure 7). The movement away from ideal path for Equatorial Guinea is evident from its high normalized cumulative path penalty, $Q^{c}$, compared to that of Sudan.

\begin{tabular}{|c|c|c|c|c|c|c|c|c|c|c|}
\hline \multicolumn{11}{|c|}{ Table 2 Selected gainers - whose ranks differed as per $G_{1}$ and $G_{2}$} \\
\hline \multirow[t]{2}{*}{ Country } & \multirow{2}{*}{$\begin{array}{c}\mathrm{HDI}_{1} \\
1990\end{array}$} & \multicolumn{3}{|c|}{$\mathrm{HDI}_{2}$} & \multirow{2}{*}{$\begin{array}{c}G_{1} \\
(1990- \\
2004)\end{array}$} & \multirow{2}{*}{$\begin{array}{c}G_{1} \\
\text { Rank, } \\
R_{1} \\
\end{array}$} & \multirow{2}{*}{$\begin{array}{c}G_{2} \\
(1990- \\
2004) \\
\end{array}$} & \multirow{2}{*}{$\begin{array}{c}G_{2} \\
\text { Rank, } \\
R_{2}\end{array}$} & \multirow{2}{*}{$\begin{array}{c}\text { Rank } \\
\text { Diff } \\
\left(R_{1}-R_{2}\right) \\
\end{array}$} & \multirow[t]{2}{*}{${ }_{\mathrm{N}} Q^{c}$} \\
\hline & & 2004 & 1990 & 2004 & & & & & & \\
\hline Equats & 0.501 & 0.652 & 0.477 & 0.569 & 0.3034 & 31 & 0.1764 & 68 & -37 & 0.0300 \\
\hline Sudan & 0.427 & 0.519 & 0.432 & 0.526 & 0.1609 & 80 & 0.1649 & 75 & 5 & 0.0013 \\
\hline Bolivia & 0.605 & 0.694 & 0.598 & 0.666 & 0.2237 & 56 & 0.1687 & 73 & -17 & 0.0046 \\
\hline India & 0.515 & 0.609 & 0.513 & 0.608 & 0.1949 & 64 & 0.1946 & 60 & 4 & 0.0002 \\
\hline Jordan & 0.685 & 0.765 & 0.685 & 0.747 & 0.2548 & 44 & 0.1966 & 58 & -14 & 0.0065 \\
\hline Turkey & 0.682 & 0.756 & 0.686 & 0.755 & 0.2324 & 52 & 0.2199 & 48 & 4 & 0.0017 \\
\hline United $S$ & 0.917 & 0.948 & 0.897 & 0.926 & 0.3749 & 23 & 0.2802 & 35 & -12 & 0.0019 \\
\hline Switzerland & 0.914 & 0.947 & 0.896 & 0.941 & 0.3844 & 21 & 0.4376 & 10 & 11 & 0.0006 \\
\hline Denmark & 0.898 & 0.943 & 0.885 & 0.923 & 0.4378 & 15 & 0.3298 & 26 & -11 & 0.0028 \\
\hline Austria & 0.897 & 0.944 & 0.886 & 0.936 & 0.4541 & 11 & 0.4381 & 9 & 2 & 0.0008 \\
\hline Paraguay & 0.721 & 0.759 & 0.715 & 0.742 & 0.1337 & 84 & 0.0945 & 94 & -10 & 0.0049 \\
\hline Algeria & 0.650 & 0.730 & 0.638 & 0.727 & 0.2281 & 54 & 0.2465 & 42 & 12 & 0.0030 \\
\hline Uruguay & 0.806 & 0.851 & 0.792 & 0.831 & 0.2331 & 51 & 0.1911 & 61 & -10 & 0.0033 \\
\hline Saudi Arabia & 0.708 & 0.777 & 0.704 & 0.779 & 0.2367 & 50 & 0.2551 & 39 & 11 & 0.0008 \\
\hline Netherlands & 0.913 & 0.947 & 0.905 & 0.933 & 0.3925 & 20 & 0.3021 & 29 & -9 & 0.0037 \\
\hline Italy & 0.890 & 0.940 & 0.879 & 0.936 & 0.4502 & 12 & 0.4726 & t & 5 & 0.0010 \\
\hline Philip & 0.722 & 0.770 & 0.703 & 0.745 & 0.1748 & 75 & 0.1411 & 79 & -4 & 0.0028 \\
\hline Sri Lanka & 0.706 & 0.759 & 0.685 & 0.742 & 0.1809 & 73 & 0.1802 & 64 & 9 & 0.0010 \\
\hline Bangladesh & 0.422 & 0.533 & 0.419 & 0.518 & 0.1910 & 66 & 0.1705 & 72 & -6 & 0.0023 \\
\hline Senegal & 0.405 & 0.464 & 0.398 & 0.463 & 0.0991 & 99 & 0.1081 & 90 & 9 & 0.0020 \\
\hline United Kingdom & 0.889 & 0.940 & 0.878 & 0.930 & 0.4555 & 10 & 0.4273 & 13 & -3 & 0.0070 \\
\hline $\begin{array}{l}\text { United Arab } \\
\text { Emirates }\end{array}$ & 0.810 & 0.842 & 0.790 & 0.827 & 0.1676 & 79 & 0.1788 & 67 & 12 & 0.0043 \\
\hline
\end{tabular}

For Bolivia, the movement away from ideal path is characterized by a slower improvement in income dimension, compared to health. In comparison, India's movement almost coincides with the ideal path. In fact the normalized cumulative path penalty, $Q^{c}$, for India is lowest among all the 127 countries considered here. Similar observation can be made in case of comparison between Philippines and Sri Lanka, where the former has almost stagnated in income dimension, whereas the movement of the later is fairly close to the ideal path (Figure 7). Another set of countries Jordan and Turkey show similar characteristics. Both these countries start with almost same level of HDI in 1990; Jordan's progress in the 
least performing income dimension is low compared to other dimensions. On the contrary, Turkey's progress has been closer to the ideal path.

Figure 7 Comparative movements of selected countries in HDI space $(y, h), 1990-2004$

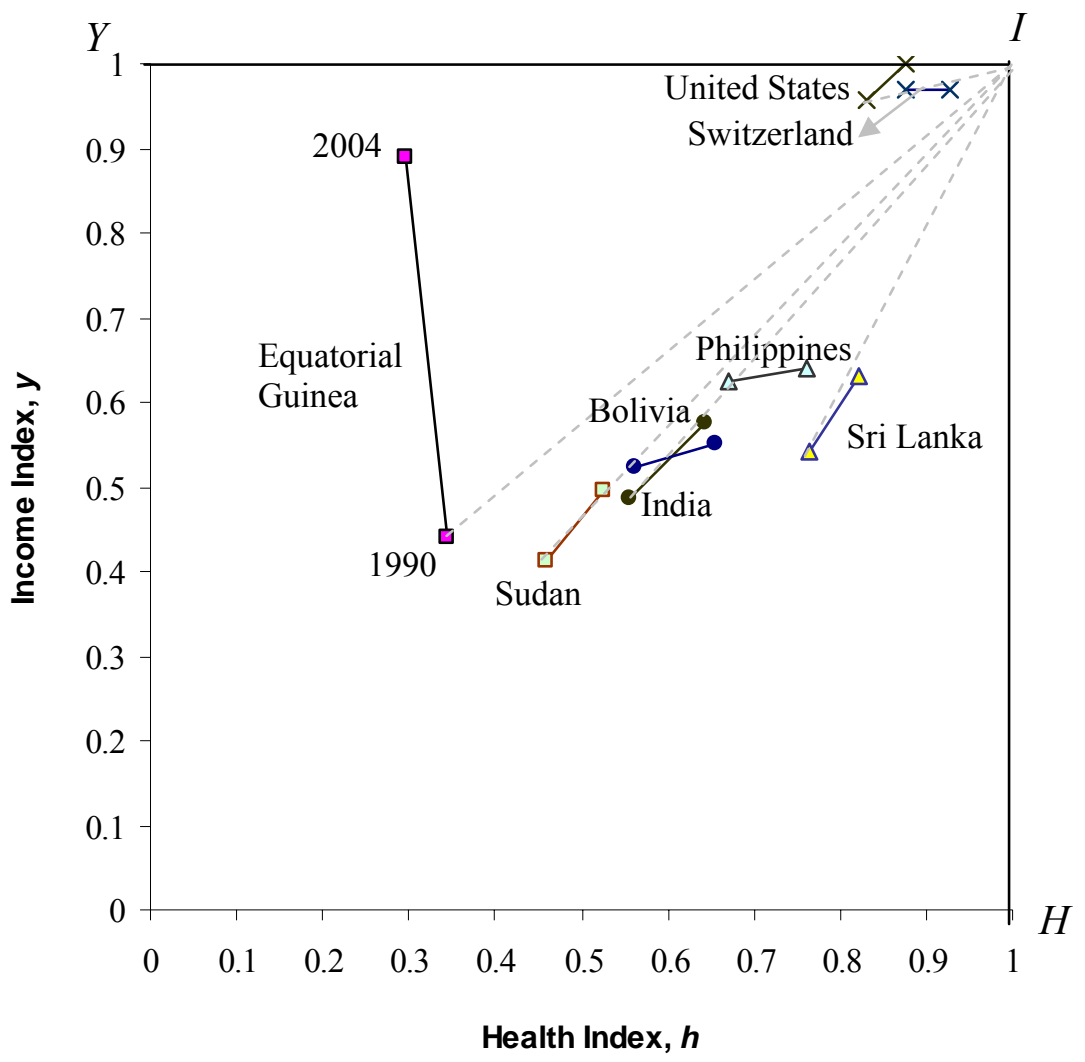

Note: The dashed line area the ideal paths for the countries considered. Since these countries are HDI gainers, that is, $G$ is positive; the direction of movement is obvious (the time period is not marked for each country because of paucity of space)

The stagnancy in a higher performing dimension is less serious. This is evident from the movement of Switzerland vis-à-vis United States. Both these countries are characterised by high income. In 1990, the income index, $y$, for Switzerland and United States are 0.969 and 0.957 respectively. By 2004, $y$ for United States was close to unity; whereas it had not changed for Switzerland. However, Switzerland has achieved more progress in health where it was relatively lower compared to its income dimension. United States could not achieve proportionate progress in health as the European countries because of its low life expectancy attributed to iniquitous health care system with relatively high ethnic diversity, income 
inequality, infant mortality and mortality from violence among young adults among other reasons (Preston and Ho, 2009).

Progress in human development in terms of $G_{\alpha}$ is dominated by developed countries. The top $19 G_{1}$ and $22 G_{2}$ countries are from the top 30 countries of 1990 as per $\mathrm{HDI}_{1}$ and $\mathrm{HDI}_{2}$ respectively. This indicates the high human development countries reducing their shortfall from ideal at a faster rate compared to lower ranked countries. China is the only developing country to find a place in top 30 counties in terms of $G_{\alpha}$. In the study period of 1990-2004, China grew at a rate of $8-9 \%$, its GNP multiplied more than five folds, life expectancy increased by three years, infant mortality decreased by half and adult literacy rate went close to $90 \%$ from $77.7 \%$ (Baige, 2006). Other countries showing improvement are Rwanda, Oman, Tunisia, Iran, Vietnam and Cape Verde.

\subsection{Fluctuation in HDI movement}

The steadiness in movement in HDI space is assessed through the measure of fluctuation, $F$. Table 3 shows the list of countries with more than 50 per cent fluctuation. The first six in the list are CIS states. The decrease of all indices and particularly the sharp decline of income indices between 1990 and 1995, immediately after their formation following disintegration of the former Soviet Union, and their recent recovery explain this high fluctuation. The economic collapse has also had repercussion beyond the CIS countries, which is evident from depression in income index in the neighbouring countries like Mongolia, Bulgaria, Romania, Estonia and Croatia.

There are 15 countries which have fluctuations less than one per cent. These include five high human development countries like Japan, Oman, Mauritius, Panama and Saudi Arabia. These countries not only show low normalized cumulative penalty $\left({ }_{\mathrm{N}} Q^{c} \leq 0.001\right)$, but also low fluctuations indicating that the sub periodic movements adhere to the ideal path. The medium development countries with similar behaviour are India, Pakistan, China and Tunisia. 
Table 3 Countries experiencing maximum fluctuations

\begin{tabular}{|c|c|c|c|c|c|c|c|c|c|c|c|c|c|c|c|}
\hline \multirow{3}{*}{ Country } & \multicolumn{12}{|c|}{ le 3 Countries experiencing maximum fluctuations } & \multirow{3}{*}{$O^{c}$} & \multirow{3}{*}{$\min \left(Q^{c}\right)$} & \multirow{3}{*}{$F$} \\
\hline & \multicolumn{4}{|c|}{ Health Index, $h$} & \multicolumn{4}{|c|}{ Education Index, $e$} & \multicolumn{4}{|c|}{ Income Index, $y$} & & & \\
\hline & 1990 & 1995 & 2000 & 2004 & 1990 & 1995 & 2000 & 2004 & 1990 & 1995 & 2000 & 2004 & & & \\
\hline Arr & 0.720 & 0.741 & 0.766 & 0.777 & 0.897 & 0861 & & & 0.598 & & 0.546 & 0.620 & & & \\
\hline Belarus & & 728 & 0 & & & & & & & & & & & & \\
\hline $\begin{array}{l}\text { Russian } \\
\text { Federatio }\end{array}$ & 0.728 & 0.687 & 0.678 & 0.670 & 940 & .918 & 0.953 & 0 & 0 & 7 & 0 . & 0.767 & + & 6673 & 0 \\
\hline & 1 & 0.752 & U & 2 & & & & & & & & & & & \\
\hline & 693 & 650 &  & 0.640 & & 10 & & & & & & & & & \\
\hline Ukr & 728 & 0.695 & 0.689 & 0.685 & & 8 & & & 0.756 & & 0.634 & & & & 345 \\
\hline Baha & 721 & 0.709 & 0.724 & 0.754 & 0.876 & 0.879 & & 0.857 & 0.872 & & 0.871 & & & & 0.6284 \\
\hline Cong & 493 & 0.443 & 0.435 & 0.455 & & & & & 0.393 & & 0.391 & & & & 0.6262 \\
\hline & & 0.725 & & 0.781 & & & & & 0.774 & & & & & & 0.6093 \\
\hline & & & & & & & & & & & & & & & \\
\hline & & 8 & & 0.6 & & & & & 71 & & 0. & & & & 290 \\
\hline & 742 & .736 & & 0.777 & & & & & & & 0.779 & & & & \\
\hline Croatia & 0.784 & 0.802 & 0.822 & 0.836 & 0.863 & 0.876 & 0.889 & 0.902 & 0.784 & 0.733 & 0.775 & 0.802 & 0.0444 & 0.0040 & 0.5093 \\
\hline
\end{tabular}




\section{$7 \quad$ Concluding remarks}

There has been an increasing focus on broader measurements of human progress to capture wellbeing, happiness, security and sustainability. Amongst all these measures, HDI stands out as the most successful and widely accepted measure (UNU-WIDER, 2007). Inclusion of direct physical quality of life measures like health and education and consideration of income as an 'indirect' indicator to value person's command over resources make HDI a 'pragmatic', though not 'pure' measure of human development (Qizilbash, 2002).

In a background paper for HDR, Molina and Purser (2010) analyse trends in HDI for the last four decades and observe that there have been substantial improvements in human development without much correlation between income growth and the other dimensions. More often than not, it is the state interventions in health and education that are relevant.

The present paper is more about measurement of HDI and its change. The conventional measure is a simple linear averaging of the three dimensions, $\mathrm{HDI}_{1}$. Under this, there is perfect substitutability across dimensions and a country with relatively higher income can get a higher value/rank even if health and education dimensions are not doing well. To address this, the current paper uses $\mathrm{HDI}_{2}$ which is an inverse of the Euclidean distance measuring shortfall from the ideal. Such an approach as well as the associated measure of normalized-change, which satisfies certain axiomatic properties, penalizes countries that give greater emphasis to one dimension while neglecting the other dimensions. Given an initial level, the latter approach also indicates an ideal path and any deviation from this is indicated through path penalty. Further, the paper proposes a measure to capture fluctuations in the movement.

Our empirical exercise was carried for the time period 1990 to 2004 . From 127 countries, 16 show movements away from ideal with incremental HDI being negative. It is not a mere coincidence that these countries are from Sub-Saharan and CIS regions. The Sub- 
Saharan countries are plagued from poor health infrastructure coupled with HIV/AIDS. The sharp decline in life expectancy in the study period has led to a movement away from ideal path for some countries of the region. CIS countries experienced a negative shock, particularly in the income dimension during 1990-1995. However, the sub-periodic analysis shows that the countries are in recovery path since 2000. The CIS countries are also characterized by high fluctuations in their movement.

The progress in human development turns out to be faster for countries already high in human development. This is because the shortfall is low for these countries in absolute terms. Also, the analysis show emerging economies like China and India have shown larger progress in HDI and movement closer to the ideal path with low fluctuations. This study can further be extended to establish policy linkages.

\section{References}

Anand, S. and Sen, A.K. (2000) 'The Income Component of the Human Development Index.' Journal of Human Development, Vol. 1, No. 1, pp 83-106.

Baige, Z. (2006) 'Human development in China', Environment on the edge, 2005-06, The United Nations Environment Programme and World Conservation Monitoring Centre (UNEP/WCMC), pp.19-28.

Campos, N.F. and Coricelli, F. (2002) 'Growth in Transition: What We Know, What We Don't and What We Should', Journal of Economic Literature, Vol. 40, No. 3, pp.793-836.

Desai, M. (1991) 'Human Developments - Concepts and measurement', European Economic Review, Vol. 35, No. 2-3, pp.350-57.

Dowling, J.M. and Wignaraja, G. (2005) 'Turning the Corner: The Economic Revival of Central Asia', Policy Studies, Vol. 3, No. 8, June.

Dowling, Malcolm \& Wignaraja, Ganeshan, (2006). 'Central Asia after Fifteen Years of Transition: Growth, Regional Cooperation, and Policy Choices' Working Papers on Regional Economic Integration, No. 3, Asian Development Bank.

Fosu, A.K. and Mwabu, G. (2010) 'Human Development in Africa ', Human Development Research Paper 2010/08, United Nations Development Programme, http://hdr.undp.org/en/reports/global/hdr2010/papers/HDRP_2010_08.pdf, [accessed 17/6/2010]. 
GMR, (2007) Confronting the Challenges of Gender Equality and Fragile States, Global Monitoring Report, Millennium Development Goals, Washington DC: The World Bank.

Haq, M. (1995) Reflections of Human Development, Oxford University Press, New York.

IMF (2005) 'Regional Economic Outlook: September 2005' Middle East and Central Asia Department, Washington D.C.: International Monetary Fund

Jahan, S. (2003) 'Evolution of the Human Development Index', in Fukuda-Parr S. and ShivaKumar A.K. (Eds.): Readings in Human Development, New York: Oxford University Press.

Linn, J.F. (2004) 'Economic (dis)integration Matters: The Soviet collapse revisited', Brookings Institution, October, http://www.brookings.edu/views/papers/200410linn.pdf, [accessed 17/6/2010].

Mishra S. and Nathan H.S.K. (2008) 'On A Class of Human Development Index Measures', Working Paper No. WP-2008-020, IGIDR, Mumbai, http://www.igidr.ac.in/pdf/publication/WP-2008-020.pdf, [accessed 17/6/2010].

Molina, G.G. and Purser, M. (2010) 'Human Development Trends since 1970: A Social Convergence Story', Human Development Research Paper 2010/02, United Nations Development Programme, http://hdr.undp.org/en/reports/global/hdr2010/papers/HDRP_2010_02.pdf, [accessed 17/6/2010].

Nathan, H.S.K, Mishra S. and Reddy, B.S. (January 2008), 'An Alternative Approach to Measure HDI', Working Paper No. WP-2008-001, IGIDR, Mumbai, http://www.igidr.ac.in/pdf/publication/WP-2008-001.pdf, [accessed 17/6/2010].

Preston S. H. and Ho J. (2009) Low Life Expectancy in the United States: Is the Health Care System at Fault? PSC Working Paper Series, PSC 09-03, University of Pennsylvania, Philadelphia, http://repository.upenn.edu/cgi/viewcontent.cgi?article=1012\&context=psc_working_papers, [accessed 16/7/2010].

Qizilbash, M. (2002) 'On the Measurement of Human Development' Lecture Prepared for the UNDP Training Course, Oxford, September, http://hdr.undp.org/en/media/Qizilbash_HDI critique.pdf, [accessed 12/6/2010].

Raworth, K. and Stewart, D. (2003) 'Critiques of the Human Development Index: A Review', in Fukuda-Parr S. and Shiva-Kumar A.K. (Eds.): Readings in Human Development, New York: Oxford University Press.

Sen, A.K. (1999) Development as Freedom, Oxford: Oxford University Press.

Sen A.K. (2000). 'A Decade of Human Development', Journal of Human Development, Vol. 1, No. 1, pp.17-23. 
Streeten, P. (1994) 'Human development: means and ends', The American Economic Review, Papers and Proceedings, Vol. 84, No. 2, pp.232-237.

UNAIDS (2008), Report on the global AIDS epidemic, 2008, Switzerland: Joint United Nations Programme on HIV/AIDS.

UNDP (2007) Human Development Report, 2007/2008, United Nations Development Programme, , New York: Oxford University Press.

UNICEF (2007) 'Fact sheet on child survival, Key Data', United Nations International Children's Emergency Fund, http://www.unicef.org/media/files/Key_data.doc, [accessed 17/6/2010].

UNU-WIDER (2007), 'Measuring Human Well-being: Key Findings and Policy Lessons', Policy brief, United Nations University-World Institute for Development Economic Research, November, 2007, http://www.unu.edu/publications/briefs/policybriefs/2007/pb03-07.pdf, [accessed 17/6/2010].

World Bank (2002) Transition: The First Ten Years: Analysis and Lessons for Eastern Europe and the Former Soviet Union, Washington D.C.: The World Bank.

Zeleny, M. A. (1974) 'Concept of Compromise Solutions and Method of Displaced Ideal', Computers and Operations Research, Vol. 1, No. 4, pp.479-496. 


\section{Appendix 1}

Table A1 HDI under linear average and displaced ideal, measure of normalized-change, cumulative path penalty and measure of fluctuation

\begin{tabular}{|c|c|c|c|c|c|c|c|c|c|c|c|c|c|c|c|}
\hline \multirow[t]{2}{*}{$\overline{\text { Country }}$} & \multicolumn{4}{|c|}{$\mathrm{HDI}_{1}$} & \multicolumn{4}{|c|}{$\mathrm{HDI}_{2}$} & \multirow{2}{*}{$\begin{array}{c}G_{1} \\
(1990- \\
2004) \\
\end{array}$} & \multirow{2}{*}{$\begin{array}{c}G_{1} \\
\text { Rank, } \\
R_{I} \\
\end{array}$} & \multirow{2}{*}{$\begin{array}{c}G_{2} \\
(1990- \\
2004) \\
\end{array}$} & \multirow{2}{*}{$\begin{array}{c}G_{2} \\
\text { Rank, } \\
R_{2} \\
\end{array}$} & \multirow{2}{*}{$\begin{array}{c}\text { Rank } \\
\text { Diff } \\
\left(R_{1}-R_{2}\right) \\
\end{array}$} & \multirow[t]{2}{*}{${ }_{\mathrm{N}} Q^{c}$} & \multirow[t]{2}{*}{$F$} \\
\hline & 1990 & 1995 & 2000 & 2004 & 1990 & 1995 & 2000 & 2004 & & & & & & & \\
\hline Australia & 0.893 & 0.933 & 0.947 & 0.957 & 0.885 & 0.919 & 0.936 & 0.949 & 0.5997 & 3 & 0.5537 & 1 & 2 & 0.0043 & 0.1809 \\
\hline Luxembourg & 0.887 & 0.913 & 0.930 & 0.945 & 0.852 & 0.880 & .904 & 0.927 & 0.5167 & 5 & 0.5051 & 2 & 3 & 0.0015 & 0.0372 \\
\hline Iceland & 0.916 & 0.921 & 0.945 & 0.960 & 0.909 & 0.916 & 0.940 & 0.955 & 0.5241 & 4 & 0.5044 &  & 1 & 0.0018 & 0.0996 \\
\hline Ireland & 0.873 & 0.897 & 0.932 & 0.956 & 0.863 & 0.887 & 0.916 & 0.932 & 0.6521 & 1 & 0.5005 & 4 & -3 & 0.0052 & 0.0412 \\
\hline Sweden & 0.901 & 0.933 & 0.949 & 0.951 & 0.892 & 0.924 & 0.939 & 0.945 & 0.5050 & 6 & 0.4933 & 5 & 1 & 0.0053 & 0.2391 \\
\hline Korea, Rep. of & 0.823 & 0.860 & 0.890 & 0.912 & 0.807 & 0.847 & 0.878 & 0.901 & 0.5044 & 7 & 0.4872 & 6 & 1 & 0.0007 & 0.0167 \\
\hline Italy & 0.890 & 0.908 & 0.924 & 0.940 & 0.879 & 0.901 & 0.918 & 0.936 & 0.4502 & 12 & 0.4726 & 7 & 5 & 0.0010 & 0.0395 \\
\hline Norway & 0.912 & 0.936 & 0.956 & 0.965 & 0.902 & 0.924 & 0.939 & 0.947 & 0.6057 & 2 & 0.4623 & 8 & -6 & 0.0026 & 0.0439 \\
\hline Austria & 0.897 & 0.916 & 0.937 & 0.944 & 0.886 & 0.907 & 0.927 & 0.936 & 0.4541 & 11 & 0.4381 & 9 & 2 & 0.0008 & 0.0574 \\
\hline Switzer & 0.914 & 0.925 & 0.941 & 0.947 & 0.896 & 0.914 & 0.934 & 0.941 & 0.3844 & 21 & 0.4376 & 10 & 11 & 0.0006 & 0.0375 \\
\hline New Zealand & 0.876 & 0.906 & 0.925 & 0.936 & 0.867 & 0.895 & 0.912 & 0.924 & 0.4879 & 8 & 0.4336 & 11 & -3 & 0.0024 & 0.0699 \\
\hline $\begin{array}{l}\text { Hong Kong, China } \\
\text { (SAR) }\end{array}$ & 0.864 & 0883 & 001 & 929 & 0.863 & 0.876 & 0.913 & 0.922 & 04802 & 9 & 0.4298 & 12 & -3 & 0.0027 & 0 \\
\hline United Kingdom & 0.889 & 0.927 & 0.939 & 0.940 & 0.878 & 0.910 & 0.923 & 0.930 & 0.4555 & 10 & 0.4273 & 13 & -3 & 0.0070 & 0.3621 \\
\hline Israel & 0.867 & 0.890 & 0.918 & 0.924 & 0.868 & 0.890 & 0.918 & 0.924 & 0.4268 & 16 & 0.4220 & 14 & 2 & 0.0016 & 0.1087 \\
\hline Belgium & 0.902 & 0.932 & 0.945 & 0.945 & 0.892 & 0.916 & 0.930 & 0.936 & 0.4383 & 14 & 0.4105 & 15 & -1 & 0.0045 & 0.3280 \\
\hline Japan & 0.914 & 0.927 & 0.939 & 0.949 & 0.906 & 0.921 & 0.934 & 0.945 & 0.4052 & 18 & 0.4101 & 16 & 2 & 0.0004 & 0.0079 \\
\hline Spain & 0.893 & 0.910 & 0.927 & 0.938 & 0.885 & 0.902 & 0.920 & 0.931 & 0.4206 & 17 & 0.3969 & 17 & 0 & 0.0016 & 0.1089 \\
\hline Franc & 0.904 & 0.923 & 0.935 & 0.942 & 0.897 & 0.916 & 0.929 & 0.937 & 0.3956 & 15 & 0.3891 & 18 & 1 & 0.0011 & 0.1092 \\
\hline Finlan & 0.904 & 0.917 & 0.938 & 0.947 & 0.891 & 0.902 & 0.922 & 0.933 & 0.4443 & 13 & 0.3865 & 19 & -6 & 0.0025 & 0.2135 \\
\hline Oman & 0.695 & 0.740 & 0.776 & 0.801 & 0.677 & 0.729 & 0.772 & 0.800 & 0.3474 & 27 & 0.3820 & 20 & 7 & 0.0010 & 0.0057 \\
\hline Cyprus & 0.846 & 0.868 & 0.893 & 0.905 & 0.842 & 0.862 & 0.888 & 0.901 & 0.3817 & 22 & 0.3750 & 21 & 1 & 0.0006 & 0.0328 \\
\hline China & 0.628 & 0.685 & 0.730 & 0.760 & 0.617 & 0.677 & 0.722 & 0.755 & 0.3548 & 25 & 0.3610 & 22 & 3 & 0.0007 & 0.0115 \\
\hline Malta & 0.828 & 0.855 & 0.876 & 0.886 & 0.829 & 0.856 & 0.878 & 0.887 & 0.3404 & 29 & 0.3424 & 23 & 6 & 0.0023 & 0.1866 \\
\hline Greece & 0.876 & 0.880 & 0.897 & 0.921 & 0.867 & 0.872 & 0.890 & 0.913 & 0.3624 & 24 & 0.3411 & 24 & 0 & 0.0025 & 0.0862 \\
\hline
\end{tabular}


Table A1 HDI under linear average and displaced ideal, measure of normalized-change, cumulative path penalty and measure of fluctuation

\begin{tabular}{|c|c|c|c|c|c|c|c|c|c|c|c|c|c|c|c|}
\hline \multirow[t]{2}{*}{ Country } & \multicolumn{4}{|c|}{$\mathrm{HDI}_{1}$} & \multicolumn{4}{|c|}{$\mathrm{HDI}_{2}$} & \multirow{2}{*}{$\begin{array}{c}G_{1} \\
(1990- \\
2004)\end{array}$} & \multirow{2}{*}{$\begin{array}{c}G_{1} \\
\text { Rank, } \\
R_{1}\end{array}$} & \multirow{2}{*}{$\begin{array}{c}G_{2} \\
(1990- \\
2004)\end{array}$} & \multirow{2}{*}{$\begin{array}{c}G_{2} \\
\text { Rank, } \\
R_{2}\end{array}$} & \multirow{2}{*}{$\begin{array}{c}\text { Rank } \\
\text { Diff } \\
\left(R_{1}-R_{2}\right)\end{array}$} & \multirow[t]{2}{*}{${ }_{\mathrm{N}} Q^{c}$} & \multirow[t]{2}{*}{$F$} \\
\hline & 1990 & 1995 & 2000 & 2004 & 1990 & 1995 & 2000 & 2004 & & & & & & & \\
\hline Portugal & 0.853 & 0.883 & 0.902 & 0.904 & 0.843 & 0.869 & 0.891 & 0.896 & 0.3478 & 26 & 0.3381 & 25 & 1 & 0.0051 & 0.2865 \\
\hline Denmark & 0.898 & 0.913 & 0.932 & 0.943 & 0.885 & 0.898 & 0.914 & 0.923 & 0.4378 & 15 & 0.3298 & 26 & -11 & 0.0028 & 0.0476 \\
\hline Chile & 0.787 & 0.818 & 0.843 & 0.861 & 0.775 & 0.809 & 0.833 & 0.849 & 0.3457 & 28 & 0.3294 & 27 & 1 & 0.0008 & 0.0405 \\
\hline Tunisia & 0.659 & 0.700 & 0.739 & 0.762 & 0.653 & 0.693 & 0.735 & 0.760 & 0.3033 & 32 & 0.3067 & 28 & 4 & 0.0010 & 0.0134 \\
\hline Netherlands & 0.913 & 0.932 & 0.944 & 0.947 & 0.905 & 0.918 & 0.929 & 0.933 & 0.3925 & 20 & 0.3021 & 29 & -9 & 0.0037 & 0.2342 \\
\hline Iran, Islamic Rep. of & 0.651 & 0.695 & 0.723 & 0.753 & 0.650 & 0.695 & 0.725 & 0.754 & 0.2901 & 35 & 0.2968 & 30 & 5 & 0.0012 & 0.0093 \\
\hline Lebanon & 0.682 & 0.729 & 0.748 & 0.777 & 0.666 & 0.722 & 0.736 & 0.765 & 0.2996 & 34 & 0.2959 & 31 & 3 & 0.0019 & 0.0888 \\
\hline Malaysia & 0.723 & 0.761 & 0.791 & 0.806 & 0.726 & 0.764 & 0.792 & 0.806 & 0.3003 & 33 & 0.2934 & 32 & 1 & 0.0009 & 0.0271 \\
\hline Bahrain & 0.812 & 0.828 & 0.842 & 0.866 & 0.809 & 0.826 & 0.842 & 0.864 & 0.2867 & 36 & 0.2878 & 33 & 3 & 0.0011 & 0.0916 \\
\hline Hungary & 0.811 & 0.815 & 0.845 & 0.869 & 0.795 & 0.800 & 0.831 & 0.854 & 0.3071 & 30 & 0.2861 & 34 & -4 & 0.0036 & 0.1558 \\
\hline United States & 0.917 & 0.930 & 0.940 & 0.948 & 0.897 & 0.909 & 0.919 & 0.926 & 0.3749 & 23 & 0.2802 & 35 & -12 & 0.0019 & 0.1260 \\
\hline Mauritius & 0.726 & 0.749 & 0.779 & 0.803 & 0.730 & 0.753 & 0.782 & 0.806 & 0.2828 & 38 & 0.2797 & 36 & 2 & 0.0005 & 0.0084 \\
\hline Poland & 0.807 & 0.820 & 0.848 & 0.862 & 0.789 & 0.802 & 0.832 & 0.848 & 0.2833 & 37 & 0.2769 & 37 & 0 & 0.0009 & 0.0657 \\
\hline Cape Verde & 0.628 & 0.679 & 0.711 & 0.725 & 0.630 & 0.677 & 0.710 & 0.726 & 0.2620 & 41 & 0.2598 & 38 & 3 & 0.0012 & 0.0249 \\
\hline Saudi Arabia & 0.708 & 0.742 & 0.765 & 0.777 & 0.704 & 0.741 & 0.766 & 0.779 & 0.2367 & 50 & 0.2551 & 39 & 11 & 0.0008 & 0.0043 \\
\hline Samoa (Western) & 0.700 & 0.742 & 0.765 & 0.778 & 0.672 & 0.720 & 0.742 & 0.755 & 0.2605 & 42 & 0.2536 & 40 & 2 & 0.0008 & 0.0463 \\
\hline Argentina & 0.813 & 0.835 & 0.860 & 0.863 & 0.802 & 0.826 & 0.846 & 0.851 & 0.2688 & 39 & 0.2486 & 41 & -2 & 0.0028 & 0.2169 \\
\hline Algeria & 0.650 & 0.672 & 0.701 & 0.730 & 0.638 & 0.666 & 0.698 & 0.727 & 0.2281 & 54 & 0.2465 & 42 & 12 & 0.0030 & 0.0291 \\
\hline Thailand & 0.717 & 0.751 & 0.775 & 0.792 & 0.708 & 0.742 & 0.761 & 0.779 & 0.2638 & 40 & 0.2444 & 43 & -3 & 0.0057 & 0.2145 \\
\hline Viet Nam & 0.618 & 0.661 & 0.696 & 0.716 & 0.592 & 0.632 & 0.667 & 0.691 & 0.2551 & 43 & 0.2420 & 44 & -1 & 0.0010 & 0.0427 \\
\hline Mexico & 0.766 & 0.784 & 0.811 & 0.823 & 0.767 & 0.783 & 0.809 & 0.819 & 0.2461 & 46 & 0.2255 & 45 & 1 & 0.0020 & 0.0710 \\
\hline Brazil & 0.720 & 0.749 & 0.785 & 0.792 & 0.721 & 0.747 & 0.773 & 0.784 & 0.2544 & 45 & 0.2246 & 46 & -1 & 0.0026 & 0.0416 \\
\hline Costa Rica & 0.793 & 0.812 & 0.832 & 0.844 & 0.781 & 0.800 & 0.820 & 0.830 & 0.2448 & 47 & 0.2228 & 47 & 0 & 0.0015 & 0.1179 \\
\hline Turkey & 0.682 & 0.713 & 0.743 & 0.756 & 0.686 & 0.716 & 0.743 & 0.755 & 0.2324 & 52 & 0.2199 & 48 & 4 & 0.0017 & 0.0428 \\
\hline Panama & 0.751 & 0.774 & 0.797 & 0.811 & 0.743 & 0.765 & 0.786 & 0.799 & 0.2401 & 48 & 0.2191 & 49 & -1 & 0.0006 & 0.0051 \\
\hline Estonia & 0.813 & 0.793 & 0.831 & 0.858 & 0.793 & 0.771 & 0.809 & 0.837 & 0.2399 & 49 & 0.2141 & 50 & -1 & 0.0098 & 0.5134 \\
\hline El Salvador & 0.651 & 0.690 & 0.715 & 0.731 & 0.655 & 0.692 & 0.715 & 0.728 & 0.2278 & 55 & 0.2125 & 51 & 4 & 0.0020 & $\begin{array}{r}0.0405 \\
\text { Contd }\end{array}$ \\
\hline
\end{tabular}


Table A1 HDI under linear average and displaced ideal, measure of normalized-change, cumulative path penalty and measure of fluctuation

\begin{tabular}{|c|c|c|c|c|c|c|c|c|c|c|c|c|c|c|c|}
\hline \multirow{2}{*}{ Country } & \multicolumn{4}{|c|}{$\mathrm{HDI}_{1}$} & \multicolumn{4}{|c|}{$\mathrm{HDI}_{2}$} & \multirow{2}{*}{$\begin{array}{c}G_{1} \\
(1990- \\
2004) \\
\end{array}$} & \multirow{2}{*}{$\begin{array}{c}G_{1} \\
\text { Rank, } \\
R_{1} \\
\end{array}$} & \multirow{2}{*}{$\begin{array}{c}G_{2} \\
(1990- \\
2004)\end{array}$} & \multirow{2}{*}{$\begin{array}{c}G_{2} \\
\text { Rank, } \\
R_{2}\end{array}$} & \multirow{2}{*}{$\begin{array}{c}\text { Rank } \\
\text { Diff } \\
\left(R_{1}-R_{2}\right)\end{array}$} & \multirow[t]{2}{*}{${ }_{\mathrm{N}} Q^{c}$} & \multirow[t]{2}{*}{$F$} \\
\hline & 1990 & 1995 & 2000 & 2004 & 1990 & 1995 & 2000 & 2004 & & & & & & & \\
\hline Egypt & 0.580 & 0.613 & 0.654 & 0.673 & 0.566 & 0.598 & 0.637 & 0.657 & 0.2218 & 58 & 0.2110 & 52 & 6 & 0.0017 & 0.0140 \\
\hline Guatemala & 0.586 & 0.617 & 0.656 & 0.678 & 0.591 & 0.623 & 0.658 & 0.678 & 0.2219 & 57 & 0.2110 & 53 & 4 & 0.0022 & 0.0094 \\
\hline Peru & 0.708 & 0.735 & 0.760 & 0.775 & 0.697 & 0.725 & 0.742 & 0.757 & 0.2286 & 53 & 0.2008 & 54 & -1 & 0.0016 & 0.0537 \\
\hline Morocco & 0.549 & 0.580 & 0.610 & 0.641 & 0.534 & 0.566 & 0.598 & 0.628 & 0.2029 & 63 & 0.2004 & 55 & 8 & 0.0020 & 0.0288 \\
\hline Indonesia & 0.626 & 0.665 & 0.682 & 0.708 & 0.620 & 0.659 & 0.673 & 0.695 & 0.2184 & 60 & 0.1975 & 56 & 4 & 0.0018 & 0.0614 \\
\hline Colombia & 0.730 & 0.754 & 0.775 & 0.790 & 0.728 & 0.751 & 0.769 & 0.782 & 0.2216 & 59 & 0.1973 & 57 & 2 & 0.0026 & 0.0306 \\
\hline Jordan & 0.685 & 0.710 & 0.744 & 0.765 & 0.685 & 0.706 & 0.729 & 0.747 & 0.2548 & 44 & 0.1966 & 58 & -14 & 0.0065 & 0.0737 \\
\hline Dominican Republic & 0.682 & 0.703 & 0.733 & 0.747 & 0.683 & 0.703 & 0.732 & 0.745 & 0.2051 & 62 & 0.1960 & 59 & 3 & 0.0011 & 0.0272 \\
\hline India & 0.515 & 0.548 & 0.577 & 0.609 & 0.513 & 0.546 & 0.577 & 0.608 & 0.1949 & 64 & 0.1946 & 60 & 4 & 0.0002 & 0.0075 \\
\hline Uruguay & 0.806 & 0.819 & 0.841 & 0.851 & 0.792 & 0.807 & 0.825 & 0.831 & 0.2331 & 51 & 0.1911 & 61 & -10 & 0.0033 & 0.1861 \\
\hline Rwanda & 0.339 & 0.337 & 0.426 & 0.465 & 0.323 & 0.307 & 0.414 & 0.451 & 0.1900 & 67 & 0.1881 & 62 & 5 & 0.0161 & 0.3098 \\
\hline Latvia & 0.803 & 0.769 & 0.815 & 0.845 & 0.785 & 0.748 & 0.794 & 0.824 & 0.2145 & 61 & 0.1816 & 63 & -2 & 0.0164 & 0.6093 \\
\hline Sri Lanka & 0.706 & 0.729 & 0.747 & 0.759 & 0.685 & 0.708 & 0.729 & 0.742 & 0.1809 & 73 & 0.1802 & 64 & 9 & 0.0010 & 0.0317 \\
\hline Albania & 0.704 & 0.704 & 0.738 & 0.759 & 0.694 & 0.692 & 0.727 & 0.749 & 0.1854 & 69 & 0.1798 & 65 & 4 & 0.0030 & 0.2182 \\
\hline $\begin{array}{l}\text { Syrian Arab } \\
\text { Republic }\end{array}$ & 0.646 & 0.673 & 0.690 & 0.712 & 0.638 & 0.669 & 0.685 & 0.703 & 0.1858 & 68 & 0.1789 & 66 & 2 & 0.0026 & 0.0659 \\
\hline $\begin{array}{l}\text { United Arab } \\
\text { Emirates }\end{array}$ & 0.810 & 0.819 & 0.833 & 0.842 & 0.790 & 0.806 & 0.822 & 0.827 & 676 & 79 & 88 & 67 & 12 & 0.0043 & 0.0814 \\
\hline Equatorial Guinea & 0.501 & 0.519 & 0.643 & 0.652 & 0.477 & 0.495 & 0.579 & 0.569 & 0.3034 & 31 & 0.1764 & 68 & -37 & 0.0300 & 0.0344 \\
\hline $\begin{array}{l}\text { Lao People's Dem. } \\
\text { Rep. }\end{array}$ & 0.451 & 0.488 & 0.523 & 0.551 & 0.450 & 0.486 & 0.521 & 0.547 & 0.1827 & 72 & 0.1764 & 69 & 3 & 0.0007 & 0.0028 \\
\hline Croatia & 0.810 & 0.803 & 0.828 & 0.847 & 0.801 & 0.790 & 0.817 & 0.836 & 0.1921 & 65 & 0.1758 & 70 & -5 & 0.0074 & 0.5093 \\
\hline Nepal & 0.425 & 0.467 & 0.500 & 0.522 & 0.409 & 0.452 & 0.488 & 0.512 & 0.1686 & 78 & 0.1731 & 71 & 7 & 0.0019 & 0.0088 \\
\hline Bangladesh & 0.422 & 0.454 & 0.510 & 0.533 & 0.419 & 0.449 & 0.495 & 0.518 & 0.1910 & 66 & 0.1705 & 72 & -6 & 0.0023 & 0.0401 \\
\hline Bolivia & 0.605 & 0.637 & 0.675 & 0.694 & 0.598 & 0.626 & 0.652 & 0.666 & 0.2237 & 56 & 0.1687 & 73 & -17 & 0.0046 & 0.0102 \\
\hline Yemen & 0.394 & 0.438 & 0.467 & 0.497 & 0.384 & 0.429 & 0.459 & 0.486 & 0.1702 & 76 & 0.1661 & 74 & 2 & 0.0033 & 0.0105 \\
\hline Sudan & 0.427 & 0.465 & 0.496 & 0.519 & 0.432 & 0.471 & 0.504 & 0.526 & 0.1609 & 80 & 0.1649 & 75 & 5 & 0.0013 & $\begin{array}{l}0.0307 \\
\text { Contd. }\end{array}$ \\
\hline
\end{tabular}


Table A1 HDI under linear average and displaced ideal, measure of normalized-change, cumulative path penalty and measure of fluctuation

\begin{tabular}{|c|c|c|c|c|c|c|c|c|c|c|c|c|c|c|c|}
\hline \multirow{2}{*}{ Country } & \multicolumn{4}{|c|}{$\mathrm{HDI}_{1}$} & \multicolumn{4}{|c|}{$\mathrm{HDI}_{2}$} & \multirow{2}{*}{$\begin{array}{c}G_{1} \\
(1990- \\
2004) \\
\end{array}$} & \multirow{2}{*}{$\begin{array}{c}G_{1} \\
\text { Rank, } \\
R_{1} \\
\end{array}$} & \multirow{2}{*}{$\begin{array}{c}G_{2} \\
(1990- \\
2004)\end{array}$} & \multirow{2}{*}{$\begin{array}{c}G_{2} \\
\text { Rank, } \\
R_{2}\end{array}$} & \multirow{2}{*}{$\begin{array}{c}\text { Rank } \\
\text { Diff } \\
\left(R_{1}-R_{2}\right)\end{array}$} & \multirow[t]{2}{*}{${ }_{\mathrm{N}} Q^{c}$} & \multirow[t]{2}{*}{$F$} \\
\hline & 1990 & 1995 & 2000 & 2004 & 1990 & 1995 & 2000 & 2004 & & & & & & & \\
\hline Belize & 0.748 & 0.770 & 0.780 & 0.794 & 0.737 & 0.758 & 0.769 & 0.779 & 0.1832 & 71 & 0.1610 & 76 & -5 & 0.0045 & 0.1530 \\
\hline Nicaragua & 0.610 & 0.642 & 0.667 & 0.679 & 0.611 & 0.639 & 0.661 & 0.672 & 0.1767 & 74 & 0.1560 & 77 & -3 & 0.0020 & 0.0099 \\
\hline Lithuania & 0.825 & 0.789 & 0.830 & 0.857 & 0.810 & 0.771 & 0.808 & 0.837 & 0.1840 & 70 & 0.1422 & 78 & -8 & 0.0183 & 0.6494 \\
\hline Philippines & 0.722 & 0.738 & 0.759 & 0.770 & 0.703 & 0.716 & 0.734 & 0.745 & 0.1748 & 75 & 0.1411 & 79 & -4 & 0.0028 & 0.0389 \\
\hline Uganda & 0.411 & 0.413 & 0.474 & 0.510 & 0.412 & 0.409 & 0.455 & 0.494 & 0.1691 & 77 & 0.1398 & 80 & -3 & 0.0122 & 0.2779 \\
\hline Pakistan & 0.463 & 0.493 & 0.511 & 0.532 & 0.457 & 0.487 & 0.507 & 0.529 & 0.1284 & 86 & 0.1326 & 81 & 5 & 0.0005 & 0.0076 \\
\hline Romania & 0.775 & 0.770 & 0.778 & 0.808 & 0.761 & 0.754 & 0.760 & 0.792 & 0.1480 & 81 & 0.1309 & 82 & -1 & 0.0042 & 0.3858 \\
\hline Chad & 0.335 & 0.344 & 0.357 & 0.420 & 0.334 & 0.347 & 0.361 & 0.420 & 0.1283 & 87 & 0.1284 & 83 & 4 & 0.0134 & 0.2089 \\
\hline Guyana & 0.684 & 0.687 & 0.716 & 0.730 & 0.657 & 0.658 & 0.683 & 0.699 & 0.1467 & 82 & 0.1218 & 84 & -2 & 0.0040 & 0.2377 \\
\hline Papua New Guinea & 0.481 & 0.514 & 0.530 & 0.544 & 0.488 & 0.520 & 0.535 & 0.549 & 0.1213 & 90 & 0.1201 & 85 & 5 & 0.0026 & 0.1388 \\
\hline Honduras & 0.625 & 0.642 & 0.654 & 0.677 & 0.624 & 0.640 & 0.650 & 0.668 & 0.1410 & 83 & 0.1187 & 86 & -3 & 0.0033 & 0.0197 \\
\hline Mauritania & 0.390 & 0.425 & 0.447 & 0.465 & 0.391 & 0.424 & 0.445 & 0.463 & 0.1237 & 89 & 0.1177 & 87 & 2 & 0.0011 & 0.0537 \\
\hline Benin & 0.372 & 0.397 & 0.416 & 0.444 & 0.365 & 0.391 & 0.414 & 0.439 & 0.1150 & 92 & 0.1170 & 88 & 4 & 0.0038 & 0.0094 \\
\hline Ghana & 0.511 & 0.531 & 0.555 & 0.572 & 0.515 & 0.536 & 0.557 & 0.571 & 0.1245 & 88 & 0.1162 & 89 & -1 & 0.0037 & 0.0098 \\
\hline Senegal & 0.405 & 0.422 & 0.439 & 0.464 & 0.398 & 0.418 & 0.438 & 0.463 & 0.0991 & 99 & 0.1081 & 90 & 9 & 0.0020 & 0.0414 \\
\hline Mongolia & 0.646 & 0.634 & 0.659 & 0.693 & 0.606 & 0.597 & 0.619 & 0.647 & 0.1306 & 85 & 0.1048 & 91 & -6 & 0.0109 & 0.5290 \\
\hline Mozambique & 0.316 & 0.330 & 0.364 & 0.395 & 0.319 & 0.335 & 0.365 & 0.389 & 0.1154 & 91 & 0.1030 & 92 & -1 & 0.0075 & 0.0412 \\
\hline Mali & 0.285 & 0.309 & 0.332 & 0.359 & 0.283 & 0.306 & 0.329 & 0.355 & 0.1034 & 97 & 0.1002 & 93 & 4 & 0.0015 & 0.0295 \\
\hline Paraguay & 0.721 & 0.740 & 0.754 & 0.759 & 0.715 & 0.732 & 0.740 & 0.742 & 0.1337 & 84 & 0.0945 & 94 & -10 & 0.0049 & 0.0931 \\
\hline Armenia & 0.738 & 0.701 & 0.736 & 0.767 & 0.709 & 0.661 & 0.696 & 0.737 & 0.1094 & 93 & 0.0941 & 95 & -2 & 0.0199 & 0.7629 \\
\hline Comoros & 0.506 & 0.521 & 0.539 & 0.557 & 0.512 & 0.525 & 0.542 & 0.557 & 0.1034 & 98 & 0.0920 & 96 & 2 & 0.0052 & 0.0177 \\
\hline Ethiopia & 0.314 & 0.322 & 0.349 & 0.377 & 0.316 & 0.327 & 0.353 & 0.379 & 0.0921 & 100 & 0.0918 & 97 & 3 & 0.0056 & 0.0473 \\
\hline Madagascar & 0.448 & 0.459 & 0.482 & 0.507 & 0.450 & 0.460 & 0.480 & 0.496 & 0.1074 & 96 & 0.0838 & 98 & -2 & 0.0083 & 0.0829 \\
\hline Bulgaria & 0.794 & 0.783 & 0.797 & 0.817 & 0.780 & 0.766 & 0.775 & 0.798 & 0.1092 & 94 & 0.0805 & 99 & -5 & 0.0074 & 0.5937 \\
\hline Burkina Faso & 0.308 & 0.312 & 0.330 & 0.355 & 0.300 & 0.307 & 0.327 & 0.352 & 0.0678 & 104 & 0.0747 & 100 & 4 & 0.0039 & 0.1310 \\
\hline Venezuela & 0.760 & 0.768 & 0.774 & 0.786 & 0.755 & 0.763 & 0.764 & 0.772 & 0.1083 & 95 & 0.0704 & 101 & -6 & 0.0044 & 0.2976 \\
\hline Trinidad and Tobago & 0.793 & 0.791 & 0.801 & 0.810 & 0.780 & 0.777 & 0.787 & 0.796 & 0.0790 & 102 & 0.0686 & 102 & 0 & 0.0065 & $\begin{array}{l}0.0685 \\
\text { Contd. }\end{array}$ \\
\hline
\end{tabular}


Table A1 HDI under linear average and displaced ideal, measure of normalized-change, cumulative path penalty and measure of fluctuation

\begin{tabular}{|c|c|c|c|c|c|c|c|c|c|c|c|c|c|c|c|}
\hline \multirow[t]{2}{*}{ Country } & \multicolumn{4}{|c|}{$\mathrm{HDI}_{1}$} & \multicolumn{4}{|c|}{$\mathrm{HDI}_{2}$} & \multirow{2}{*}{$\begin{array}{c}G_{1} \\
(1990- \\
2004)\end{array}$} & \multirow{2}{*}{$\begin{array}{c}G_{1} \\
\text { Rank, } \\
R_{1}\end{array}$} & \multirow{2}{*}{$\begin{array}{c}G_{2} \\
(1990- \\
2004)\end{array}$} & \multirow{2}{*}{$\begin{array}{c}G_{2} \\
\text { Rank, } \\
R_{2}\end{array}$} & \multirow{2}{*}{$\begin{array}{c}\text { Rank } \\
\text { Diff } \\
\left(R_{1}-R_{2}\right)\end{array}$} & \multirow[t]{2}{*}{${ }_{\mathrm{N}} Q^{c}$} & \multirow[t]{2}{*}{$F$} \\
\hline & 1990 & 1995 & 2000 & 2004 & 1990 & 1995 & 2000 & 2004 & & & & & & & \\
\hline Guinea-Bissau & 0.313 & 0.341 & 0.353 & 0.357 & 0.312 & 0.340 & 0.354 & 0.359 & 0.0639 & 105 & 0.0684 & 103 & 2 & 0.0085 & 0.0489 \\
\hline Niger & 0.246 & 0.254 & 0.268 & 0.287 & 0.238 & 0.249 & 0.264 & 0.283 & 0.0544 & 106 & 0.0581 & 104 & 2 & 0.0036 & 0.0556 \\
\hline Nigeria & 0.407 & 0.419 & 0.433 & 0.454 & 0.405 & 0.414 & 0.421 & 0.438 & 0.0782 & 103 & 0.0562 & 105 & -2 & 0.0132 & 0.0473 \\
\hline Jamaica & 0.719 & 0.725 & 0.737 & 0.743 & 0.713 & 0.718 & 0.724 & 0.729 & 0.0861 & 101 & 0.0535 & 106 & -5 & 0.0057 & 0.0364 \\
\hline Togo & 0.498 & 0.507 & 0.504 & 0.515 & 0.491 & 0.501 & 0.503 & 0.514 & 0.0347 & 108 & 0.0440 & 107 & 1 & 0.0120 & 0.0496 \\
\hline Bahamas & 0.823 & 0.812 & 0.831 & 0.826 & 0.808 & 0.797 & 0.814 & 0.814 & 0.0139 & 114 & 0.0299 & 108 & 6 & 0.0109 & 0.6284 \\
\hline Burundi & 0.351 & 0.325 & 0.344 & 0.370 & 0.353 & 0.331 & 0.347 & 0.370 & 0.0287 & 109 & 0.0266 & 109 & 0 & 0.0150 & 0.2368 \\
\hline Belarus & 0.788 & 0.753 & 0.775 & 0.794 & 0.762 & 0.718 & 0.742 & 0.764 & 0.0269 & 110 & 0.0094 & 110 & 0 & 0.0181 & 0.6807 \\
\hline Malawi & 0.372 & 0.414 & 0.398 & 0.399 & 0.371 & 0.386 & 0.373 & 0.374 & 0.0425 & 107 & 0.0061 & 111 & -4 & 0.0178 & 0.0572 \\
\hline Kazakhstan & 0.768 & 0.723 & 0.736 & 0.774 & 0.741 & 0.691 & 0.703 & 0.735 & 0.0265 & 111 & -0.0082 & 112 & -1 & 0.0225 & 0.6406 \\
\hline Tanzania, U. Rep. of & 0.437 & 0.423 & 0.420 & 0.451 & 0.434 & 0.416 & 0.408 & 0.429 & 0.0260 & 112 & -0.0104 & 113 & -1 & 0.0225 & 0.1156 \\
\hline Congo & 0.528 & 0.533 & 0.502 & 0.525 & 0.509 & 0.515 & 0.488 & 0.502 & -0.0060 & 115 & -0.0140 & 114 & 1 & 0.0197 & 0.6262 \\
\hline Cameroon & 0.515 & 0.495 & 0.502 & 0.524 & 0.515 & 0.497 & 0.494 & 0.503 & 0.0189 & 113 & -0.0235 & 115 & -2 & 0.0232 & 0.0974 \\
\hline Côte d'Ivoire & 0.443 & 0.428 & 0.427 & 0.430 & 0.442 & 0.430 & 0.429 & 0.431 & -0.0309 & 117 & -0.0244 & 116 & 1 & 0.0179 & 0.0470 \\
\hline Russian Federation & 0.818 & 0.771 & 0.785 & 0.797 & 0.795 & 0.746 & 0.754 & 0.764 & -0.0259 & 116 & -0.0390 & 117 & -1 & 0.0231 & 0.6616 \\
\hline Ukraine & 0.800 & 0.748 & 0.755 & 0.774 & 0.781 & 0.720 & 0.720 & 0.744 & -0.0326 & 118 & -0.0476 & 118 & 0 & 0.0279 & 0.6345 \\
\hline Tajikistan & 0.697 & 0.631 & 0.627 & 0.652 & 0.657 & 0.571 & 0.567 & 0.598 & -0.0646 & 122 & -0.0899 & 119 & 3 & 0.0335 & 0.4858 \\
\hline Moldova, Rep. of & 0.740 & 0.683 & 0.679 & 0.696 & 0.714 & 0.637 & 0.627 & 0.648 & -0.0592 & 121 & -0.0923 & 120 & 1 & 0.0316 & 0.3327 \\
\hline Kenya & 0.548 & 0.525 & 0.504 & 0.518 & 0.541 & 0.514 & 0.481 & 0.486 & -0.0550 & 119 & -0.1000 & 121 & -2 & 0.0313 & 0.0850 \\
\hline Zambia & 0.464 & 0.425 & 0.409 & 0.437 & 0.452 & 0.404 & 0.382 & 0.399 & -0.0587 & 120 & -0.1166 & 122 & -2 & 0.0300 & 0.2298 \\
\hline South Africa & 0.735 & 0.741 & 0.691 & 0.662 & 0.723 & 0.717 & 0.658 & 0.603 & -0.0991 & 123 & -0.1653 & 123 & 0 & 0.0470 & 0.0972 \\
\hline Lesotho & 0.572 & 0.573 & 0.524 & 0.501 & 0.560 & 0.560 & 0.487 & 0.441 & -0.1251 & 124 & -0.2122 & 124 & 0 & 0.0593 & 0.0190 \\
\hline Botswana & 0.680 & 0.660 & 0.598 & 0.568 & 0.681 & 0.654 & 0.551 & 0.484 & -0.1645 & 125 & -0.2890 & 125 & 0 & 0.0842 & 0.0054 \\
\hline Swaziland & 0.622 & 0.604 & 0.536 & 0.506 & 0.618 & 0.584 & 0.486 & 0.431 & -0.1859 & 126 & -0.3022 & 126 & 0 & 0.0745 & 0.0165 \\
\hline Zimbabwe & 0.639 & 0.591 & 0.525 & 0.494 & 0.630 & 0.564 & 0.477 & 0.439 & -0.2263 & 127 & -0.3035 & 127 & 0 & 0.0716 & 0.0439 \\
\hline
\end{tabular}

$\mathrm{HDI}_{1}$ and $\mathrm{HDI}_{2}$ are Human Development Index (HDI) under linear average and displaced ideal respectively and $G_{1}$ and $G_{1}$ are their respective

measure of normalized-change. 